Article

\title{
Is Automobile Dependence in Emerging Cities an Irresistible Force? Perspectives from São Paulo, Taipei, Prague, Mumbai, Shanghai, Beijing, and Guangzhou
}

\author{
Jeffrey R. Kenworthy ${ }^{1,2}$ \\ 1 Curtin University Sustainability Policy Institute, Curtin University, Perth 6102, Australia; \\ j.kenworthy@curtin.edu.au or jeffrey.kenworthy@fb1.fra-uas.de \\ 2 Frankfurt University of Applied Sciences, 60598 Frankfurt am Main, Germany
}

Received: 2 October 2017; Accepted: 19 October 2017; Published: 27 October 2017

\begin{abstract}
This paper analyses seven metropolitan regions that are all experiencing rapid motorisation and are perhaps appearing to capitulate to the automobile. Through 20 years of changes, evidenced in systematic data from the mid-1990s, a different perspective is found. None of the urban regions appear near to or even capable of becoming automobile cities. Physical limits are already being reached that make higher levels of private motorised mobility very problematic if transport systems are to remain functional and the cities livable. These limits appear already to be reversing the decline in non-motorised modes and creating an upturn in transit systems, especially urban rail. That these cities have been able to either hold their own, or somewhat increase their share of total motorised mobility by transit over a 20-year period, is some indication that they are 'hitting mobility walls' much sooner in the motorisation path than cities in North America and Australia, which grew up with and were designed around the spatial needs of cars. Like many cities in the developed world that have shown a decoupling of car use and total passenger mobility from GDP growth from 1995 to 2005, there is now evidence that this is happening in less wealthy cities. This is important because it assists global and local goals for reduced $\mathrm{CO}_{2}$ from passenger transport, while allowing for economic progress. Such evidence suggests that automobile dependence is not an irresistible force in emerging economies.
\end{abstract}

Keywords: auto-dependence; sustainability; emerging economies; transit; non-motorised modes; mobility; congestion; density; walking city; transit city; auto city; São Paulo; Taipei; Prague; Mumbai; Shanghai; Beijing; Guangzhou; emerging transit cities

\section{Introduction: Automobile Dependence and Its Sustainability Context}

One of the many problems confronting all cities is passenger transport with its attendant social, economic, environmental, and resource sustainability problems, especially those related to dependence on the automobile and its widespread impacts. Amongst the foremost issues facing urban transport are its prodigious energy demand and its contribution to global $\mathrm{CO}_{2}$ production. Additionally, automobile dependence creates local and regional air pollution, such as photochemical smog, particulates and carcinogenic benzene emissions [1], and a host of other local problems, such as noise, destruction of public environments, and reduced food growing and green areas through sprawl [2-6].

Globally, the transport sector is highly dependent on non-renewable liquid fossil fuels, is a major consumer of the world's remaining conventional oil reserves (predominantly in the Middle East) and a significant contributor to global $\mathrm{CO}_{2}$ and climate change. Robert Cervero [7], states that:

"The transportation sector is ... responsible for 13 percent of Greenhouse Gas (GHG) emissions worldwide and 23 percent of total energy-related GHG emissions [8]. If recent trends hold, the sector's 
share of global GHG emissions could reach 40 percent by 2050 [9]. Fueling this increase is the growing demand for urban mobility ... The transport sector's share of global oil demand grew from 33 percent in 1971 to 47 percent in 2002 and by one account could reach 54 percent by 2030 if past trends hold [10]. With increasing motorization and investments in roads and highways, cities find themselves in a vicious cycle-reliance on the private car unleashes more sprawl and road building further increases reliance on the private car" [7] (p. 2).

Automobile dependence in North America and Australia and the cities of other developed regions, is clear, though even within these regions, the magnitude of that dependence varies a great deal. American cities are the most automobile dependent cities in the world, followed by Australian cities. Conversely, Canadian cities, while being automobile-dependent, occupy a niche between the extreme auto-dependence of cities in the USA and Australia, and the more modest dependence on cars in European cities [3-5,11-15]. On the other hand, cities in emerging economies in Latin America, Asia, and some parts of Eastern Europe have a reputation for rapid motorisation, as evidenced by often chronic congestion and air pollution, such as reported in Beijing and São Paulo. Based on such visible and overwhelming evidence, clearly cars and motorcycles are becoming more important in the mobility patterns of such cities.

The implication is that such cities are becoming automobile dependent, meaning that the automobile is becoming a dominant mode in mobility patterns, with very high car ownership and use and that the choice and ability to use public transport (transit), walking, and cycling (non-motorised modes-NMM) are diminishing. It furthermore implies that land use patterns are being re-shaped around the car into low density, heavily zoned forms. Typically, auto-dependent cities have about $80 \%$ or more of all daily trips by private transport modes (cars, motorcycles, and taxis), often ranging up to as high as $95 \%[12,16]$.

Charles Lave [17] set out what he believes to be the natural transition of cities towards automobile dependence, as the expectations of urban residents rise and they become wealthier and thus presumably more able to afford what he considers to be the most desirable and attractive mode of mobility - the car. Lave classed automobile dependence as an "irresistible force". Paul Barter [18,19], on the other hand, has provided a detailed, empirically-based study of East and South East Asian cities, which suggests a range of urban mobility transition opportunities, which can result in different "end states". He considers that rather than automobile dependence being an irresistible force in emerging economies, the evolution of their mobility patterns will depend greatly on the policy and transport investment decisions that they make. Such decisions can be in favour of investment in transit, walking, and cycling, or the development of high capacity roads and more parking and they can either facilitate unbridled car ownership and use, or implement restrictions on car ownership and use through financial and/or physical means as, for example, Singapore has done. Craig Townsend [20] has clearly shown similar conclusions through detailed case studies of major transport infrastructure decisions in Bangkok, Kuala Lumpur, and Singapore, and the very different results these have produced in terms of motorisation and mobility choices.

More recently, Geels et al. [21] have demonstrated the complexities involved in all or any "transitions" surrounding "automobility" and its many facets and dimensions. In other words, in the context of the present paper, the literature reveals a nuanced future for the automobile and automobile dependence, which depends on many factors and forces at work in cities. This is especially critical in emerging economies where the dual pressures of population and vehicle growth threaten to overwhelm their urban environments. Finally, Frans Sengers [22] provides a very detailed account of the many problems and possibilities facing Bangkok in its efforts to develop more sustainable transport, suggesting that the development of automobile dependence or its opposite, is subject to a myriad of complexities and how they play out in the real world.

Some key questions at the heart of this paper then become:

- How far can rapidly motorising cities in emerging economies reach in terms of their automobile dependence? Will they become like the Los Angeles of the world? 
- As they get wealthier with increasing metropolitan GDP per capita and quality of life expectations rise, will there be an inevitable trend towards greater automobile dependence?

- Are there any built-in limitations in such cities in the development of automobile dependence?

- What can such cities do to minimise automobile dependence?

\section{Methodological Approach}

The research presented here relies heavily on the international comparative data, which the author has been collecting and publishing for 40 years (referred to in this paper as the "global cities database"). All the cities have a baseline set of either 1995 or 1996 data, depending on the Census year of the country [12] and a still largely unpublished, updated set of data for at least 2005 or 2006 (Taipei and Prague) and in the other cities, later data, generally post-2010.

The collection of these data often takes many years due to its problematic nature, the need to identify sources and verify them, sometimes seeking permissions, and the fact that often such data are, anyway, only available at irregular intervals or with large gaps. So, there is often at least a 7 to 8 -year time lag in what can be reported on a city at any time. This global city research and history is described in detail in Kenworthy [23], but the following summarises the approach.

Each metropolitan area and its Central Business District (CBD) are first defined, corresponding to, or as close as possible to, the functional urban region or commuter belt. Data are then initially sought through comprehensive internet source searches. The required data on population, jobs, land use, metropolitan GDP, private and public transport infrastructure and mobility patterns, economic data on transport systems, transport emissions, transport fatalities and private and public passenger transport energy consumption data, are spread across the online presence of innumerable government institutions and sometimes other websites.

When these sources are exhausted, as they generally are quite quickly, then the very much more time consuming work begins of trying to locate possible sources of outstanding data. A significant amount of the required data are simply not normally published items, for example, annual vehicle kilometres and passenger kilometres of travel (VKT and PKT) for passenger cars and motorcycles and must be found, often through the output of computerized traffic models or other sources such as surveys (e.g., the Australian Bureau of Statistics (ABS) regular Survey of Motor Vehicle Usage (SMVU), though, even here, they do not publish data on cities and must be paid to extract these data for Australian metropolitan regions). Likewise, items such as the consumption of energy in private passenger transport often takes a long time to finalise before the best estimate for an urban region can be established.

The nature of the data collection work in this research is highly detailed. For example, data for all of the items on public transport systems (e.g., vehicle and seat kilometres of service, boardings, passenger kilometres, length of reserved public route, vehicle fleets, and so on) are collected for all of the modes and every operator, no matter how small. Tokyo (35 million people), for instance, demanded that each public transport item be collected 49 times before finalising any of it public transport indicators (8 public rail operators, 21 private rail operators, 3 public bus operators and 17 private bus operators). This alone took over three years to achieve.

Once all primary data are collected, then standardized comparable data are calculated. Here, it is very important that, for example, numerator and denominator match both the same physical area and the same year. Since this data collection by the author has spanned over a 40-year period, all data are also subject to detailed reality testing of the resulting standardised items to ensure bogus data have not been supplied. Further contact with those who supplied data may be necessary at this stage.

This paper will seek answers to the questions raised in the introduction through case studies of seven cities in China (Beijing, Shanghai, Guangzhou, and Taipei-Taiwan's national status is contested. It is considered by the Chinese government to be formally part of The Peoples' Republic of China (PRC)), Eastern Europe (Prague), India (Mumbai), and Latin America (São Paulo), which contain 
key data on recent changes in mobility patterns and related factors that permit investigation of these questions and allow some common patterns to be seen and overall conclusions to be drawn.

\section{São Paulo}

The São Paulo Metropolitan Region (Região Metropolitana de São Paulo) is comprised of 39 municipalities with a population today exceeding 21 million. The City of São Paulo is the largest of these totaling around 12 million. São Paulo is the largest metropolitan area in the southern hemisphere and one of the ten largest in the world (World Population Review, 2017). Data on the São Paulo Metropolitan Region (SPMR), collected over several years, show that São Paulo's most obvious transport problems stem from the cars and motorcycles that deteriorate the region's public environments and have created some of the largest traffic jams in history [24]. Table 1 presents key data on the SPMR for 1996 and more recently, mostly 2011.

Perhaps surprisingly, cars and motorcycles still only contribute about $30 \%$ of the region's daily trip making needs, despite the GDP per capita of the region having risen by $153 \%$ in real US dollars (and in real local currency, by 126\%) from 1996 to 2009. The congestion and sheer impact of traffic in turn stems primarily from the physical inability of the present urban fabric and infrastructure systems to cope with the unrestrained space demands of cars, and to a lesser extent, motorcycles. So much of São Paulo's very dense, mixed-use urban fabric was never built for the automobile and is unable to handle even its still comparatively modest levels of car and motorcycle ownership.

Cars and motorcycles therefore have a visual and physical impact that is disproportionate to the magnitude of their actual role in mobility. Metaphorically, like in many other dense, road-constrained urban regions, accommodating these vehicles in the urban fabric is like trying to fit square pegs into round holes. This is despite the SPMR having more than doubled its per capita linear availability of freeways.

As explained in the introduction about mobility issues in rapidly motorising urban regions, São Paulo's outward appearances and problems would perhaps suggest an urban region that is moving inexorably towards a sprawling and automobile dependent model of development akin to the USA. However, the evidence from the data collected for both 1996 and 2011 are contrary to that. The overall picture can be summarised as follows:

(1) São Paulo is dense and getting denser (85.5 persons per ha, up 12\% from 1996).

(2) It remains highly centralised in jobs ( $28 \%$ in the CBD) and the CBD is serviced by an expanding metro and commuter rail system.

(3) Transit service levels are very high by global standards and increasing significantly (vehicle and seat kilometres per capita rose by $32 \%$ and $21 \%$ respectively over 15 years).

(4) While buses remain clearly dominant within the transit system, their growth is faltering compared to rail and the region is moving towards a much greater role for its metro and suburban/commuter rail systems (bus passenger $\mathrm{km}(\mathrm{PKT})$ per capita declined by $4 \%$ while the metro rose $45 \%$, suburban rail rose $139 \%$ and rail travel overall increased $94 \%$ ).

(5) The relative speed of transit when compared to cars has improved and is good as compared to automobile cities (up 11 to $0.79 \%$ ). The metro and suburban rail systems both have average operating speeds that far surpass that of the road system (road traffic averages $25.4 \mathrm{~km} / \mathrm{h}$ when compared to 37.5 and $40.0 \mathrm{~km} / \mathrm{h}$ for the metro and suburban trains, respectively).

(6) Modal splits and trip making suggest that cars and motorcycles did not increase their share of all of the trips including walking, but have, conversely, experienced a small negative change from 1997 to 2007 (32.0 to 29.6\%), while transit has increased its share from 32.9 to $36.4 \%$ (the latest Household Travel Survey is 2007). However, NMM mode share has declined from 35.1 to $33.9 \%$ (still a healthy level and not declining radically—see [5]). 
(7) The combined use of transit and NMM for daily trips (70.3\%) remains dramatically higher than in any automobile cities. São Paulo is even significantly higher than in the more attractive European cities that have traditionally been characterised as strongholds of transit and NMM [25].

(8) The relatively small (29.6\%) of daily trips that are made by car and motorcycle in the SPMR are causing most of the damage (congestion, air pollution, traffic noise and traffic mortality) and are chiefly responsible for the region's reputation as a traffic disaster.

(9) Car use per capita has increased in São Paulo but not as much as perhaps the clogged road system would suggest (car PKT per capita was up by $10 \%$ and car VKT per capita by $17 \%$ over 15 years). US cities still have 4.5 times more car use per capita [5] and the indications so far are that São Paulo will not and cannot even contemplate auto-dependence levels close to any automobile city, wherever that auto city is located. The SPMR's high density is a clear factor behind this. Typical auto city densities average around 15 per ha.

(10) Motorcycle ownership and use are dramatically up in percentage terms (235\% and $167 \%$, respectively) and are high when compared to most other cities, but motorcycles remain minor in overall mobility with both per capita car and transit use (PKT) each individually exceeding motorcycle mobility by factors greater than ten.

(11) Transit boardings and PKT per capita show relatively strong growth $(27 \%$ and $14 \%$, respectively over fifteen years) and this is especially true of rail $(61 \%$ and $94 \%$ for boardings and PKT, respectively). Though buses are still the mainstay of the transit system (70\% of total transit PKT in 2011), their percentage share is declining ( $82 \%$ in 1996).

(12) The cost recovery from São Paulo's heavily used transit system is very much higher than in typical automobile dependent cities and approaches break even (91\%), though down slightly from 1996 (93\%).

(13) Total transport emissions per capita have declined by $15 \%$ and are significantly below those in the automobile cities [5].

(14) The proportion of São Paulo's motorised transport task accomplished by transit is almost the same in $2011(45.5 \%)$ as it was in $1996(45.8 \%)$, which is very high globally and some fifteen times greater than in US cities.

At least partly due to the above facts about changes in São Paulo from 1996 to 2011, the region displays a clear decoupling of car use from growth in real local GDP. From 1996 to 2011, the car kilometres per unit of real GDP (Brazilian Real) fell by $48 \%(0.466 \mathrm{~km}$ to $0.240 \mathrm{~km}$ per real R\$). This decline is also a minimum because the real GDP that has been used is for 2009 (the latest available) while the car use is for 2011, which both favour a higher car travel level per unit of GDP.

Similarly, total motorised travel per unit of real local GDP has also fallen by $50 \%$ (1.344 to 0.679 passenger $\mathrm{km}$ per real $\mathrm{R} \$$ ). Again, the decline is minimised because car, motorcycle and transit use are all for 2011, while real GDP is 2009. Kenworthy [26] contains a detailed discussion of similar trends for over 40 cities worldwide.

Despite some trends towards more freeways, a deteriorating ratio between the length of quality reserved transit route and the length of freeways (3.31 to 1.32), and a still very high transport death rate (14.1 per 100,000 persons, but down from 24.1 in 1996), the SPMR is not displaying any of the key characteristics of automobile dependent regions. Rather, the data show that the SPMR is clearly automobile saturated, where even its medium level of car ownership, compounded by a rapidly rising motorcycle fleet, simply cannot be accommodated in a dense urban structure that is not designed around the car and one that has no chance of simply building its way out of this congestion with new roads. The SPMR's dense urban structure is a positive benefit and a distinct advantage over auto-dependent regions. It is the mismatch between its urban form and lack of enough transit and NMM infrastructure, which is the main problem $[18,19,27]$. The fact that $70 \%$ of daily trips are still dependent on transit and NMM shows rather that investment should be primarily directed into these 
modes, not freeways, thus consolidating or increasing this significant advantage when compared to auto-dependent regions.

Furthermore, without some physical or economic restraints on the ownership and use of cars (and motorcycles), there appears to be little chance for São Paulo to control the congestion that cripples both cars and buses, or to stop the relative decline of buses, as described here. To ignore the need to control congestion will perpetuate and worsen what is already a morally questionable situation for the millions of people who collectively make over 4.4 billion bus boardings per year and must travel at an average speed under $17 \mathrm{~km} / \mathrm{h}$ because of the cars that clog all of the available road space.

Table 1. Key variables for the São Paulo Metropolitan Region in 1996 and more recently.

\begin{tabular}{lccc}
\hline \multicolumn{1}{c}{ Urban Transport Indicators } & $\mathbf{1 9 9 6}$ & Recent & Year \\
\hline Key Private Transport and Land Use Variables & & & \\
\hline GDP per capita (USD 1995) & $\$ 5319$ & $\$ 13,438$ & 2009 \\
Urban density (persons per ha) & 76.6 & 85.5 & 2011 \\
Percentage of jobs in the CBD & $29.2 \%$ & $27.8 \%$ & 2011 \\
Length of road per person (m) & 2.49 & 2.25 & 2011 \\
Length of freeway per person (m) & 0.009 & 0.019 & 2011 \\
Passenger cars per 1000 persons & 305 & 365 & 2011 \\
Motorcycles per 1000 persons & 22 & 73 & 2011 \\
Total car vehicle kilometres per capita (VKT) & 2417 & 2820 & 2011 \\
Total car passenger kilometres per capita (PKT) & 3650 & 4004 & 2011 \\
Total motorcycle VKT per capita & 118 & 316 & 2011 \\
Total motorcycle PKT per capita & 130 & 347 & 2011 \\
\hline Key Transit Variables & & & \\
\hline Total transit vehicle kilometres per capita & 84 & 111 & 2011 \\
Total transit seat kilometres per capita & 3759 & 4566 & 2011 \\
Total transit boardings per person & 249 & 316 & 2011 \\
- Bus boardings per person & 191 & 223 & 2011 \\
- Rail boardings per person & 57 & 93 & 2011 \\
Total transit passenger kilometres per person & 3196 & 3630 & 2011 \\
- Bus passenger kilometres per person & 2627 & 2525 & 2011 \\
- Rail passenger kilometres per person & 569 & 1106 & 2011 \\
Ratio of transit speed to road traffic speed & 0.71 & 0.79 & 2011 \\
Ratio of reserved transit route to freeways & 3.31 & 1.32 & 2011 \\
Transit farebox recovery ratio & $92.9 \%$ & $90.7 \%$ & 2011 \\
\hline Modal Split for Total Daily Trips & & & \\
\hline Daily trips by non-motorised modes & $35.1 \%$ & $33.9 \%$ & 2007 \\
Daily trips by motorised public modes & $32.9 \%$ & $36.4 \%$ & 2007 \\
Daily trips by motorised private modes & $32.0 \%$ & $29.6 \%$ & 2007 \\
\hline Modal Split for Mechanised Total Daily Trips & & & \\
\hline Daily trips by mechanised, non-motorised modes & $0.8 \%$ & $1.2 \%$ & 2007 \\
Daily trips by motorised public modes & $50.3 \%$ & $54.5 \%$ & 2007 \\
Daily trips by motorised private modes & $48.9 \%$ & $44.3 \%$ & 2007 \\
Transport emissions per capita (kg: CO, NO & 134 & 114 & 2011 \\
Total transport-related deaths per 100,000 persons & 24.1 & 14.1 & 2011 \\
Percentage of total motorised PKT on transit & $45.8 \%$ & $45.5 \%$ & 2011 \\
\hline & & & \\
\hline & & & \\
\hline
\end{tabular}

This is not much better than the typical speed for an urban bike trip. Buses annually transport over 50 billion PKT in the SPMR and yet add a burden of only 1.6 billion VKT to the road system to achieve this mobility service. Cars carry 80 billion PKT per annum but add a burden of 56 billion VKT. The public bus system that reaches and serves more people than the present rail system and contributes $62 \%$ as much PKT as the car with only 3\% as much VKT, drowns in the congestion that is created by the unrestrained use of cars and has lost any competitive advantage it once may have had.

The physical realities and constraints of the SPMR mean that automobiles and motorcycles cannot provide mobility needs within the average person's 65 to $70 \mathrm{~min}$ daily travel time budget $[28,29]$. Buses suffer similar problems. There thus appears to be an adjustment process occurring at an urban 
system level. This adjustment, perhaps hidden by the more imposing picture of road chaos and the sheer physical impacts of so many vehicles squeezed into a space that cannot contain them, is characterised by:

- densification of the city;

- failure of extra road capacity to solve traffic problems (compounded with high capacity roads' high costs and their destruction of the city's public environments and impacts on NMM);

- rail becoming a favoured mode because of its superior relative speed, made more striking by buses not competing in speed terms through lack of enough dedicated rights-of-way (it does have Bus Rapid Transit (BRT) lines); and,

- increasing attraction of rail station precincts as development sites because of accessibility advantages.

São Paulo will capitalize on their rail station precincts for urban development. The city is using value capture to fund infrastructure and has become rather successful at it. Leão Serva [30] states:

"City leaders identify a redevelopment zone, and issue a number of bonds to be sold to developers at auction. The bonds entitle the developers to build bigger buildings than the law would normally allow. Revenue from the bond sales are invested back into housing, roads and other infrastructure in the same redevelopment zone ... And the auctions have yielded the city a massive windfall. In 12 years, São Paulo has raised about R $\$ 4.5$ billion, or close to $\$ 2$ billion in U.S. dollars, through these sales".

In conclusion, São Paulo is not becoming an automobile-dependent city. Both car use and total motorised mobility over the 1996 to 2011 period decoupled significantly from growth in GDP despite rapid motorisation where major increases in wealth are generally believed to drive increases in car use, something Lave [17] called an "irresistible force". Contrariwise, São Paulo is a megaregion that is maintaining a strong transit and walking orientation in the face of major increases in cars and motorcycles, which are unable to meet more than about one-third of mobility needs, but which cause traffic mayhem.

The region demonstrates the clear physical limits on how much car and motorcycle use dense, rapidly growing cities can support before hitting a wall of mobility limitations, environmental impacts, social inequity, and severe negative livability outcomes. This collision forces other adjustments, the beginnings of which we see reflected in São Paulo's data, especially the decoupling of mobility from real growth in GDP. São Paulo has been able to increase its GDP per capita by $126 \%$ (real local currency), while its per capita PKT in cars and motorcycles has grown by only $15 \%$ over 15 years and transit mobility by only $14 \%$. These adjustments could be the seeds of more sustainable transport involving a limit on, and ultimately a reversal in, the growth of automobile use and even further use of non-auto modes, while still allowing real economic growth. A key missing item in this adjustment process, in common with every other city in the world, is the direct, region-wide control of congestion and priority for buses despite numerous BRT lines [31].

\section{Taipei}

Taipei is the capital of Taiwan or the Republic of China, formerly known as Formosa or considered to be part of the PRC. Taiwan is one of the four "Asian Tigers", known for their very rapid economic growth since the 1960s. The Taipei metropolitan area consists of Taipei City and Taipei County (now New Taipei City), an area that today consists of around seven million people (there also now exists the Taipei-Keelung metropolitan area, which includes Keelung City and has a total population at 31 July 2017 of 7,043,533). Taipei has a well-developed transit system consisting of a metro, some suburban rail services, and a complex and largely integrated bus system. It is, however, better known along with a handful of other Asian metropolises, such as Ho Chi Minh City, and to a lesser extent Bangkok and Jakarta, for its extremely high motorcycle ownership rate. 
Paul Barter [18] classified Taipei as a "motorcycle city". This was distinct from other typical classifications of cities such as walking, transit, and auto city typologies, which were conceived based on the transport evolution of modern-day developed cities [4,32]. Likewise, "motorcycle city" is also distinct from more recent classifications of large global cities [33] and German cities [34] through cluster analysis, the first of which led to six distinct archetypes termed auto, transit, non-motorised mode, hybrid, paratransit, and traffic-saturated cities. Taipei fell into the "traffic-saturated cities" along with Ho Chi Minh City, Jakarta, Kuala Lumpur, Bangkok, Cairo, and Tehran. It is not surprising that the cities most oriented to motorcycles fell into the traffic-saturated cluster since motorcycle proliferation is often a direct response to chronic congestion (see later discussion).

Taipei is also very dense (170 persons per ha in 2006), which places it firmly in an urban category, where walking, cycling, and transit are very important in mobility (Table 2). It also means that it has a very constrained and compact urban form where space, especially road space, is used very intensively and is at a premium. These physical factors, combined with rapid economic growth and rising consumer expectations surrounding mobility, make Taipei an interesting comparison from the Asian region in a period of very rapid motorisation.

Taipei has clearly experienced some sweeping changes in transport from 1996 to 2006. On the one hand, motorcycles have increased dramatically, while cars have also increased, though relatively modestly. The key findings from Table 2 are:

(1) Urban and job density declined over the decade ( $-26 \%$ and $-21 \%$, respectively), though Taipei retains very high densities by global standards ( 170 persons per ha and 76 jobs per ha), which are almost four times typical European city densities and about half that of Hong Kong [5].

(2) Centralization increased marginally from $14.4 \%$ of metropolitan jobs to $15.3 \%$, which coincides with the rapid development of Taipei's metro and its focus on central locations.

(3) Wealth, expressed in both real US dollars and real NT dollars, grew significantly over the decade (32\% and $95 \%$, respectively). At $\$ 20,502$ (US dollars, 1995) in 2006, the city was still well below the overall average for cities in the author's global cities database [5], but was relatively close to the average for Singapore and Hong Kong in the same year $(\$ 21,201)$.

(4) The freeway length per capita in Taipei increased by over three times from 0.011 to $0.035 \mathrm{~m}$ per person. Although a large increase, the figure was still rather low by global standards, though a little higher than two of its Asian neighbours (Singapore and Hong Kong), which had $0.026 \mathrm{~m}$ per person in 2005.

(5) Parking availability in the newly defined CBD was a lot higher than in 1996 (337\% increase), but at 119 spaces per 1000 jobs was still extremely low by comparison to most cities. Automobile cities often exceed 500 spaces per 1000 CBD jobs [5].

(6) Transit lines were rationalised and reduced (66\% decline), though the supply of high quality reserved route for transit more than doubled (metro system and suburban rail).

(7) Car ownership increased moderately (29\%), but at 225 cars per 1000 persons was still modest (other cities in the global database in 2005 or 2006 averaged 512). However, it was very much higher in car ownership than its two Asian neighbors.

(8) Motorcycle ownership grew dramatically (150\%) and stood at 491 motorcycles per 1000 persons in 2006. The average for all cities in the database for 2005 or 2006 was only 28.

(9) Road traffic speed was very slow by global standards $(17.0 \mathrm{~km} / \mathrm{h})$, but did not deteriorate over the decade.

(10) Transit service per person (VKT) declined (-10\%), but increased in its rail component, while the seat kilometres of service per person expanded by $1 \%$, despite a fall in bus VKT (due to the large increase in rail with more seats per wagon than buses).

(11) Transit speed improved (up $18 \%$ from $13.3 \mathrm{~km} / \mathrm{h}$ to $15.7 \mathrm{~km} / \mathrm{h}$ ) due to the rail system and the ratio of transit system speed to road traffic improved (15\%). The metro speed was nearly twice road traffic speed $(32.7 \mathrm{~km} / \mathrm{h})$, while suburban rail was 2.7 times faster $(46.0 \mathrm{~km} / \mathrm{h})$. 
(12) NMM share grew slightly from 25.9 to $27.4 \%$, while transit increased from 17.6 to $18.2 \%$. Consequently, the mode share for private motorised modes declined from 56.4 to $54.4 \%$.

(13) Car use per person (VKT) increased over the decade by $16 \%$ but still only stood at $2100 \mathrm{~km}$ per person, a very low rate compared to the other global cities $(7312 \mathrm{~km})$, but higher than the Singapore-Hong Kong average of $1333 \mathrm{~km}$ [5].

(14) On the other hand, car passenger travel (passenger kilometres per person) declined by $7 \%$ due to a reduction in average occupancy.

(15) Motorcycle vehicle and passenger kilometres grew by $73 \%$ and $48 \%$ respectively and at $2158 \mathrm{~km}$ and $2438 \mathrm{~km}$ per capita were very high compared to other cities (a meager $104 \mathrm{~km}$ and $133 \mathrm{~km}$ per capita respectively).

(16) Transit boardings and passenger kilometres per capita grew to a significant degree (29\% and $16 \%$, respectively). Annual boardings registered a healthy 340 per capita (compared, for example, to the European cities with 386) and the proportion of the total motorised passenger transport task by transit increased from 25 to $26 \%$, despite the rise in car and motorcycle use.

(17) Total passenger transport energy use rose $12 \%$ over the decade, but transport emissions and transport deaths per capita declined dramatically ( $48 \%$ and $65 \%$ ). This may be due to better emissions technology and standards, as well as some shift to transit and possibly safer vehicles, despite the dramatic rise in motorcycles, which are typically more dangerous.

Table 2. Key variables for the Taipei Metropolitan Region in 1996 and 2006.

\begin{tabular}{|c|c|c|}
\hline Urban Transport Indicators & 1996 & 2006 \\
\hline \multicolumn{3}{|l|}{ Key Private Transport and Land Use Variables } \\
\hline GDP per capita (USD 1995) & $\$ 15,491$ & $\$ 20,502$ \\
\hline Urban density (persons per ha) & 230.1 & 170.1 \\
\hline Job density (jobs per ha) & 96.0 & 75.8 \\
\hline Percentage of jobs in the CBD & $14.4 \%$ & $15.3 \%$ \\
\hline Parking spaces per 1000 CBD jobs & 27 & 119 \\
\hline Length of freeway per person (m) & 0.011 & 0.035 \\
\hline Passenger cars per 1000 persons & 174 & 224 \\
\hline Motorcycles per 1000 persons & 196 & 491 \\
\hline Total car vehicle kilometres per capita (VKT) & 1813 & 2100 \\
\hline Total car passenger kilometres per capita (PKT) & 3064 & 2835 \\
\hline Total motorcycle VKT per capita & 1247 & 2158 \\
\hline Total motorcycle PKT per capita & 1647 & 2438 \\
\hline Annual private passenger transport energy use per capita (MJ) & 9554 & 10,659 \\
\hline \multicolumn{3}{|l|}{ Key Transit (PT) Variables } \\
\hline Total transit vehicle kilometres per capita & 80 & 72 \\
\hline Total transit seat kilometres per capita & 2298 & 2322 \\
\hline Total transit boardings per person & 263 & 340 \\
\hline - Bus boardings per person & 257 & 172 \\
\hline - Rail boardings per person & 5 & 168 \\
\hline Total transit passenger kilometres per person & 1598 & 1848 \\
\hline - Bus passenger kilometres per person & 1516 & 1221 \\
\hline - Rail passenger kilometres per person & 82 & 627 \\
\hline Length of transit lines per capita (m/1000 person) & 2436 & 823 \\
\hline Length of reserved PT route per person (m/1000 person) & 0.011 & 0.023 \\
\hline Ratio of transit speed to road traffic speed & 0.80 & 0.92 \\
\hline Ratio of reserved transit route to freeways & 0.97 & 0.65 \\
\hline \multicolumn{3}{|l|}{ Modal Split for Total Daily Trips } \\
\hline Daily trips by non-motorised modes & $25.9 \%$ & $27.4 \%$ \\
\hline Daily trips by motorised public modes & $17.6 \%$ & $18.2 \%$ \\
\hline Daily trips by motorised private modes & $56.4 \%$ & $54.4 \%$ \\
\hline \multicolumn{3}{|l|}{ Modal Split for Mechanised Total Daily Trips } \\
\hline Daily trips by mechanised, non-motorised modes & $4.8 \%$ & $4.9 \%$ \\
\hline Daily trips by motorised public modes & $22.7 \%$ & $23.8 \%$ \\
\hline Daily trips by motorised private modes & $72.5 \%$ & $71.3 \%$ \\
\hline Transport emissions per capita $\left(\mathrm{kg}: \mathrm{CO}, \mathrm{NO}_{\mathrm{x}}, \mathrm{VHC}, \mathrm{SO}_{2}\right)$ & 93 & 48 \\
\hline Total transport-related deaths per 100,000 persons & 18.4 & 6.4 \\
\hline Percentage of total motorised PKT on transit & $25.3 \%$ & $25.9 \%$ \\
\hline
\end{tabular}


Taipei, like São Paulo, clearly has a motorisation problem in its motor vehicle growth and usage and all that this implies for integrity of the public realm and livability of the city. But it is also clear that like São Paulo, adjustments took place (e.g., mode share for private transport fell slightly, transit use grew significantly, especially rail use, alongside a small increase in walking and cycling). The region is not succumbing to private transport in its aggregate mobility patterns and many of the trends are positive.

Finally, the car and motorcycle VKT per unit of real GDP (NT \$) in 1996 and 2006 declined by 41\% and $11 \%$, respectively. When these two pillars of private mobility in Taipei are combined, there was $29 \%$ less private motorised travel to generate one unit of real local GDP.

When considering total motorised mobility (car, motorcycle and transit PKT per unit of real local GDP), there was a $42 \%$ decline. It therefore appears that despite motorisation, urban travel in Taipei in each component has decoupled from GDP growth.

\section{Prague}

Prague, the capital of the Czech Republic is a medium size European city, which in 2017 stood at around 1.33 million [35] and is the largest city in the Czech Republic and around the fifteenth largest in the European Union, though clearly it is very much smaller than São Paulo and Taipei. From 1995 to 2005, its population, in common with many "shrinking" European cities, declined from 1,212,655 to $1,181,610$, a reduction of $2.6 \%$, but it has started to grow again. It occupies a relatively compact administrative area of $485 \mathrm{~km}^{2}$, which if considered as circular, has a radius of only about $12.5 \mathrm{~km}$. Only about $55 \%$ of this area $\left(267 \mathrm{~km}^{2}\right)$ is urbanized, the rest is forest, agriculture, and undeveloped land (all data collected from authorities by the author for the global cities database).

Prague consists of a beautiful mediaeval center, which is famous worldwide for its historic landmarks and listed by UNESCO as a World Heritage Site. Mobility in this area is strongly oriented to walking and cycling as well as transit, since it is served by a very extensive tram system and many metro stations. Outside of the historic inner area, much of the post-World War II development consists of communist era high-rise buildings often set in windswept, bleak open spaces, though frequently very close to the metro system or connected to metro stations by feeder buses.

From 1948 to 1989 Prague was under communist rule and lay behind the "Iron Curtain". In 1989 the Velvet Revolution occurred, after which Prague became part of a parliamentary republic. Czechoslovakia was split up in 1993 into the Czech Republic and Slovakia. Since 1989 the city has rapidly motorised and like most former eastern bloc cities, this motorisation has put heavy pressure on urban fabrics and transport infrastructure that were designed primarily around non-automobile modes (walking and transit city urban fabric-see [32]). In 1981, while still under communist rule, the number of cars in Prague was 284,756 for 1,183,000 people (241 per 1000 people), a not insignificant car ownership rate when considering the socio-economic and political situation [36]. By comparison, car ownership in Copenhagen in 2005 was still only 333 per 1000 [16].

By 1990, just after the Velvet Revolution, cars had grown to 336,037 (about 5700 extra cars each year) for 1,215,000 people (277 per 1000 people). However, after that, cars grew much more rapidly [36]. By 2005, Prague exceeded 500 cars per 1000 people, a rate that surpassed even that of Montreal, Toronto, and Vancouver, and was only a little behind the high car ownership of some German cities, such as Düsseldorf (516) and Stuttgart (531).

This rise in car ownership was followed by a steady growth in car use. From 1971 to 1981 daily car VKT grew from 3543 to 4338 million and then nine years later in 1990, 5848 million. However, in only one decade from 1990 to 2000 the figure leapt to over 2.5 times higher (15,131 million kilometers) and has grown steadily since [36]. Conversely, Prague also has an exceptional transit system, partly a heritage of its time under communist rule. In 2005, it had $2085 \mathrm{~km}$ of bus lines, $559 \mathrm{~km}$ of tram line, $54 \mathrm{~km}$ of metro and $160 \mathrm{~km}$ of suburban rail line or nearly $3000 \mathrm{~km}$ of transit routes, equaling nearly six kilometers of transit route within every square kilometer of its total land area. Perth (Australia), a city of similar population size, had less than one kilometer of transit route per square kilometer. 
Melbourne (Australia) is recognized as having one of the most extensive trams systems in the world, but by comparison in 2006, Melbourne's trams had a system length of $341 \mathrm{~km}$, despite having low densities and thus a need for longer transit lines. In 1995 Prague had an astonishing 907 annual transit boardings per capita, by far the highest in the hundred cities surveyed. Prague massively exceeded even one of the world's great transit cities, Zurich, which had 505 boardings per capita and eclipsed the transit giant, Tokyo, with 611 boardings per capita [12].

It is therefore interesting to dissect urban transport in Prague a little more carefully to see what has been happening in this period of rapid motorisation and again to examine the extent of changes in mobility in the face of this growth in cars and car use. Is Prague becoming an automobile dependent city, or are there signs of a more sustainable approach?

Prague is a city of stark contrasts in both the character and aesthetics of its built form. However, both its more typical European style five-storey apartment buildings with shops underneath and its high-rise neighbourhoods, are all serviced relatively well by transit, make the structure of the city more amenable to walking, cycling, and transit than to the automobile or indeed the motorcycle. Prague's extensive, expanding and heavily utilized transit system also acts as a bulwark against car and motorcycle mobility. From 1995 to 2005 Prague's transit boardings per capita grew by $16 \%$ to 1051 per capita per annum, or nearly three trips per person each day and the highest transit use the author has found in 40 years of research on this subject (Table 3). The annual distance travelled by transit also increased from 4321 to 5190 PKT per capita, or over $14 \mathrm{~km}$ per day on transit for every person. These results contradict any possible perceptions that the transit system may diminish due to the automobile.

Nevertheless, it is very clear that motorisation has developed at a high rate since the end of communism. It could perhaps be said that cars have been taken up with even more relish than in other European cities, as part of an overall trend towards greater personal freedoms, opportunities, consumerism, and wealth since democratisation.

Table 3 shows on the negative side that:

(1) Densities declined, as did the centralisation of jobs in the central city, probably not surprisingly due to significant re-orientation around the car.

(2) Parking spaces per 1000 CBD jobs increased $175 \%$ but remained relatively low at 132 (only 13 parking bays for every 100 jobs that must be accessed in the CBD).

(3) Linear freeway provision per capita remained almost unchanged over the ten years (3\% increase).

(4) There was, however, a significant increase in car ownership to 507 cars per 1000 persons (15\%) and motorcycle ownership crept up by $8 \%$ to 52 per 1000 persons (almost double the global cities database average of 28 for 2005).

(5) Car use (both per capita VKT and PKT) has increased significantly $(62 \%)$, while the equivalent factors for motorcycles were $55 \%$ and $35 \%$ respectively for the 10 years.

(6) Due to the above changes and a trend towards more fuel-consuming vehicles, per capita energy use in private motorised passenger transport increased $126 \%$.

(7) The speed competitiveness of transit relative to average road traffic speed declined from 0.94 to 0.85 , though the latter is still comparatively high for an entire transit system.

(8) Finally, transit travel (PKT) lost a little mode share relative to private motorised transport $(49.7 \%$ to $42.3 \%$ ), but this was still very much higher than the European cities average in 2005 of $24.5 \%$.

On the positive side, Table 3 also reveals that:

(1) Both transit VKT and SKT increased significantly (16\% and $9 \%$ respectively), partly perhaps due to decreased densities and longer travel distances needed for transit services.

(2) Transit boardings and PKT per capita rose $16 \%$ and $20 \%$, respectively, with most of this increase being in the rail modes (trams, metro, and suburban rail-bus PKT per capita declined and boardings only rose $4 \%$ ).

(3) The length of transit lines per capita grew $(10 \%)$, as did reserved route $(16 \%)$, and the ratio of the length of reserved transit route to freeways (12\%). 
(4) Despite the trend to cars, the modal split for private motorised modes declined from 29.3 to $25.1 \%$ of all daily trips, the gain being in transit, while NMM decreased a fraction.

(5) The lion's share of daily motorised trip making in Prague was done by transit (67\%).

(6) Per capita emissions from all transport declined by 53\%, despite greater motorisation, while transport deaths per 100,000 decreased $43 \%$.

Table 3. Key variables for Prague in 1995 and 2005.

\begin{tabular}{|c|c|c|}
\hline Urban Transport Indicators & 1995 & 2005 \\
\hline \multicolumn{3}{|l|}{ Key Private Transport and Land Use Variables } \\
\hline GDP per capita (USD 1995) & $\$ 9145$ & $\$ 20,179$ \\
\hline Urban density (persons per ha) & 48.8 & 44.2 \\
\hline Job density (jobs per ha) & 31.6 & 27.7 \\
\hline Percentage of jobs in the CBD & $37.3 \%$ & $15.7 \%$ \\
\hline Parking spaces per 1000 CBD jobs & 48 & 132 \\
\hline Length of freeway per person (m) & 0.059 & 0.061 \\
\hline Passenger cars per 1000 persons & 442 & 507 \\
\hline Motorcycles per 1000 persons & 48 & 52 \\
\hline Total car vehicle kilometers per capita (VKT) & 3104 & 5033 \\
\hline Total car passenger kilometers per capita (PKT) & 4346 & 7047 \\
\hline Total motorcycle VKT per capita & 20 & 31 \\
\hline Total motorcycle PKT per capita & 22 & 34 \\
\hline Annual private passenger transport energy use per capita (MJ) & 8253 & 18,624 \\
\hline \multicolumn{3}{|l|}{ Key Transit (Public Transport) Variables } \\
\hline Total transit vehicle kilometers (VKT) per capita & 123 & 143 \\
\hline Total transit seat kilometers (SKT) per capita & 5924 & 6444 \\
\hline Total transit boardings per person & 907 & 1051 \\
\hline - Bus boardings per person & 270 & 280 \\
\hline - Rail boardings per person & 637 & 771 \\
\hline Total transit passenger kilometres per person & 4321 & 5190 \\
\hline - Bus passenger kilometres per person & 1213 & 982 \\
\hline - Rail passenger kilometres per person & 3108 & 4208 \\
\hline Length of transit lines per capita (m/1000 person) & 2190 & 2419 \\
\hline Length of reserved PT route per person (m/1000 person) & 202 & 235 \\
\hline Ratio of transit speed to road traffic speed & 0.94 & 0.85 \\
\hline Ratio of reserved transit route to freeways & 3.45 & 3.85 \\
\hline \multicolumn{3}{|l|}{ Modal Split for Total Daily Trips } \\
\hline Daily trips by non-motorised modes & $24.9 \%$ & $24.3 \%$ \\
\hline Daily trips by motorised public modes & $45.8 \%$ & $50.6 \%$ \\
\hline Daily trips by motorised private modes & $29.3 \%$ & $25.1 \%$ \\
\hline \multicolumn{3}{|l|}{ Modal Split for Mechanised Total Daily Trips } \\
\hline Daily trips by mechanised, non-motorised modes & $2.4 \%$ & $0.4 \%$ \\
\hline Daily trips by motorised public modes & $59.6 \%$ & $66.6 \%$ \\
\hline Daily trips by motorised private modes & $38.1 \%$ & $33.0 \%$ \\
\hline Transport emissions per capita $\left(\mathrm{kg}: \mathrm{CO}, \mathrm{NO}_{\mathrm{x}}, \mathrm{VHC}, \mathrm{SO}_{2}\right)$ & 127 & 60 \\
\hline Total transport-related deaths per 100,000 persons & 10.1 & 5.8 \\
\hline Percentage of total motorised PKT on transit & $49.7 \%$ & $42.3 \%$ \\
\hline
\end{tabular}

Considering car use in relation to wealth, from 1995 to 2005 car kilometers per unit of real local GDP (CZK) reduced by 1.6\% (0.0128 to 0.0126). A similar though stronger picture emerges for all motorised mobility (car, motorcycle, and transit). In 1995, there were 0.036 total motorised PKT per CZK and in 2005 there were 0.031 , a reduction of over 14\%. Put another way, Prague's real wealth grew from 243,303 CZK per capita in 1995 to 400,523 CZK in 2005, a 65\% increase, while car mobility and total motorised mobility used to generate each Czech Crown, declined. 
When comparing Prague's car use relative to GDP with other global cities, a common currency is needed, in this case 1995 US dollars. Even though Prague had 0.249 car km per 1995 US dollar, which is atypically high for a European city (European average for the global cities database was 0.134), it is still less than the auto cities of the USA and Australia/New Zealand, which averaged 0.297 and 0.272 , respectively.

Nevertheless, it is also clear that there has been a significant increase in the spatial intensity of car use and its impact on the physical environment. This is visible, for example, in more traffic, more parked cars and more impact on the public realm of the city, giving perhaps the impression of a city that is heading strongly towards automobile dependence.

So, is Prague becoming an automobile dependent city, or are there more positive signs? As in the case of São Paulo and Taipei, the data point to a city where the visibility and prominence of the car belies the car's (and motorcycle's) role in urban mobility. Cars and motorcycles, for all the environmental impact they have in a compact city like Prague, account for only $25 \%$ of all trips, and this is a reduction relative to 1995 when they accounted for $29 \%$.

When combined with a high amount of travel by transit and a decoupling of GDP growth from growth in car use and mobility generally, this suggests that Prague is not succumbing to automobile dependence or becoming an automobile city. It is rather maintaining its basic character as a city that is strongly oriented to transit (perhaps even getting stronger) and is resilient enough to withstand the very rapid growth in car numbers and car use. As explained in Newman and Kenworthy [5], Prague appears to have reached some limits and system adjustments seem to be taking place that are beginning to limit the role that the car can play. The role of transit is being reasserted, especially the rail modes and NMM are still healthy.

Prague has some cultural features that have probably helped in this process. The city is culturally oriented to transit, as evidenced by its high per capita transit use and this is at least partly due to its heritage as one of the former eastern bloc cities, most of which developed extensive and highly utilized transit systems with very cheap fares as part of the social and political philosophy. It also has around 6.4 million international tourists annually (2014), with many using the transit system. It is the fifth most visited city in Europe (http:/ / en.wikipedia.org/wiki/Prague accessed 2 October 2017). Transit trips by tourists are included in the Prague transit usage data. Even if every 2014 visitor to the city took ten boardings on the transit system, this would amount to 64 million transit boardings in 2005. The total number of transit boardings in Prague in 2005 was 1242 million, so tourist traffic would amount to $5.1 \%$ of usage under this assumption. Prague cannot afford to lose the attraction of its historic quarters to automobile impacts, nor can it easily accommodate further increases in private motorised mobility.

\section{Mumbai, Shanghai, Beijing, and Guangzhou: Introduction and Context}

The following four case studies analyse changes in mobility and related factors in the context of some previous research on city archetypes. The data involved is not as comprehensive as the previous three cities but is enough to draw some conclusions. Cities can be classified into different transport archetypes according to a selection of relevant land use and transport data. J.M. Thomson [37] was the first to adopt this approach in Great Cities and Their Traffic. This is useful in a policy sense in that it enables cities' key characteristics, strengths, and weaknesses to be simplified and analysed and their prospects for the future to be considered. Using the Millennium Cities Database for Sustainable Transport [12] containing data for 1995 or 1996, a cluster analysis was performed on the 'megacities' from this global database [33]. The six city clusters were:

- Hybrid Cities

- Transit Cities

- Non-Motorised Cities

- Auto Cities 
- Traffic Saturated Cities

- Paratransit Cities.

The four cities in the Non-Motorised (NMM) cluster were Mumbai, Beijing, Shanghai, and Guangzhou. Since 1995, many changes have occurred in urban transport, such as peak car [38-40]. This is most true of the NMM cluster of Chinese and Indian cities, particularly huge declines in the traditional modes of walking, cycling, and other forms of non-motorised transport. China particularly has undergone extraordinary motorisation [41]. India is becoming increasingly wealthy, with a significant increase in its vehicle population. All of the cities in India and China have traditionally been strongly oriented to NMM, due to very dense urban environments and mixed land uses that accompany this, leading to very short trip distances amenable to these non-powered modes. Low income is also a factor. The NMM cluster average density was the highest of all the clusters with 194 persons per ha in 1995 (Table 4).

These case studies explore changes in the NMM cities and to summarise the changes and come to some conclusions about which cluster each of these four original NMM cities might now fit. In the discussion of each city, a more general picture is developed of the urban transport and planning issues in NMM cities.

Table 4. Key characteristics of each of the six city clusters in 1995 [33].

\begin{tabular}{|c|c|c|c|c|c|c|}
\hline Variable & $\begin{array}{l}\text { NMM } \\
\text { Cities }\end{array}$ & $\begin{array}{l}\text { Para-Transit } \\
\text { Cities }\end{array}$ & $\begin{array}{c}\text { Traffic-Saturated } \\
\text { Cities }\end{array}$ & $\begin{array}{l}\text { Transit } \\
\text { Cities }\end{array}$ & $\begin{array}{l}\text { Hybrid } \\
\text { Cities }\end{array}$ & Auto Cities \\
\hline GDP per capita (USD 1995) & $\$ 2003$ & $\$ 2848$ & $\$ 5197$ & $\$ 28,570$ & $\$ 26,236$ & $\$ 21,180$ \\
\hline Urban density (persons per ha) & 194 & 71 & 192 & 169 & 35 & 21 \\
\hline Length of road per person $(\mathrm{m})$ & 0.36 & 1.97 & 0.63 & 1.99 & 4.26 & 6.95 \\
\hline Length of freeway per person (m) & 0.002 & 0.014 & 0.019 & 0.020 & 0.096 & 0.175 \\
\hline Passenger cars per 1000 persons & 25 & 126 & 126 & 175 & 486 & 482 \\
\hline Motorcycles per 1000 persons & 49 & 6 & 157 & 63 & 17 & 7 \\
\hline Car vehicle kilometres per person (VKT) & 359 & 1328 & 1169 & 2083 & 7743 & 11,094 \\
\hline Transit boardings per person & 337 & 213 & 190 & 464 & 173 & 16 \\
\hline Daily trips by non-motorised modes (\%) & $61 \%$ & $38 \%$ & $31 \%$ & $26 \%$ & $20 \%$ & $3 \%$ \\
\hline Daily trips by public modes (\%) & $25 \%$ & $30 \%$ & $20 \%$ & $35 \%$ & $13 \%$ & $1 \%$ \\
\hline Daily trips by private modes (\%) & $14 \%$ & $32 \%$ & $49 \%$ & $38 \%$ & $67 \%$ & $95 \%$ \\
\hline
\end{tabular}

\section{Data Perspectives from 1995}

It is necessary to first understand the characteristics of each city cluster for the variables that have been harnessed for this paper (Table 4). There are significant differences between the clusters on these key land use, wealth, and transport characteristics. The NMM cities in 1995 had very low income, very high density, extremely low road supply, and especially very meager freeway provision. Car ownership was also tiny in an international perspective, though they had moderately high levels of motorcycle ownership. Transit use was high, the second highest behind the Transit Cities themselves. The use of walking and cycling for daily trips was radically higher than in any other group and transit as a proportion of total daily trips was also healthy (third highest). Finally, the NMM cities had the lowest use of private motorised modes.

In analysing changes over approximately a 20-year period, these data will be compared to recent values of the variables for each of the four cities. This method is not attempting to redo the original cluster analysis, but it is providing some strong indicative results about which direction each city may have moved.

\section{Mumbai}

\subsection{Key Data}

Table 5 summarises the key data used to assess Mumbai in recent times as compared to the mid-1990s. 
Table 5. Key variables for the Mumbai Metropolitan Region in 1996 and recently.

\begin{tabular}{lccc}
\hline \multicolumn{1}{c}{ Urban Transport Indicators } & $\mathbf{1 9 9 6}$ & Recent & Year \\
\hline Key Transport and Land Use Variables & & & \\
\hline GDP per capita (USD 1995) & $\$ 913$ & $\$ 4194$ & 2012 \\
Urban density (persons per ha) & 337.4 & 314.8 & 2011 \\
Length of road per person (m) & 0.35 & 0.40 & 2013 \\
Passenger cars per 1000 persons & 21.2 & 68.4 & 2014 \\
Motorcycles per 1000 persons & 32.2 & 122.5 & 2014 \\
Total transit boardings per person & 224.6 & 232.4 & 2015 \\
- Bus boardings per person & 103.2 & 105.0 & 2015 \\
- Rail boardings per person & 121.4 & 127.4 & 2015 \\
\hline Modal Split for Total Daily Trips & & & \\
\hline Daily trips by non-motorised modes & $49.8 \%$ & $60.3 \%$ & 2006 \\
Daily trips by motorised public modes & $40.9 \%$ & $31.9 \%$ & 2006 \\
Daily trips by motorised private modes & $9.3 \%$ & $7.8 \%$ & 2006 \\
\hline Modal Split for Mechanised Total Daily Trips & & & \\
\hline Daily trips by mechanised, non-motorised modes & $1.7 \%$ & $3.0 \%$ & 2006 \\
Daily trips by motorised public modes & $80.0 \%$ & $78.0 \%$ & 2006 \\
Daily trips by motorised private modes & $18.2 \%$ & $19.0 \%$ & 2006 \\
\hline
\end{tabular}

\subsection{Urban Density}

The Mumbai Metropolitan Region (MMR) today constitutes around 22 million people, up from 17 million people in 1996. In 1996, it was the second densest city in the global cities database (337 persons per ha), behind only Ho Chi Minh City with 356 per ha and ahead of Hong Kong with 320 per ha. It is not possible to radically change such high density over 20 years, unless vast areas are bulldozed and rebuilt at radically lower density. Of course, bulldozing of informal settlements in such cities does occur, but in practice these dense settlements are replaced with modern high rise towers because of the extremely high value, well-located land, which the informal settlements occupy today. Lower density development occurs principally in peripheral areas of lower value land, which entails long travel distances [42].

The urban density of the MMR in 2001 had only reduced by $2.6 \%$ to 329 per ha and later in 2011, when the population was 20 million, the density had fallen further to 315 per ha, or a $6.7 \%$ decline over 15 years (urban land had increased from 50,594 ha or $11.9 \%$ of the total land area in 1996, to 63,540 ha in 2011, or $15.0 \%$ of the total land area). So, despite having fallen in density from 337.4 per ha to 314.8 per ha in 15 years, the MMR remains as one of the world's densest urban environments of the modern era and one where only $15 \%$ of its total land area is urbanized [42].

\subsection{Road Supply}

Such enormous density has a radical impact on urban transport and shapes mobility patterns in a profound way, as already explained in the previous case studies, and much earlier by Thomson [43]. The physical form of any metro area critically shapes what is and is not possible in mobility terms, though it is not the only factor.

For example, if a city is as dense as Mumbai its supply of road space is severely constrained. Mumbai in 1996 had a meager $0.35 \mathrm{~m}$ of road length per person $(35 \mathrm{~cm})$ and the average for the NMM cluster was $0.36 \mathrm{~m}$ per person.

In the automobile-dependent megacities in the same year, the road length per person was $6.95 \mathrm{~m}$ or just under 20 times more. Even the traffic-saturated cities, whose main feature is overwhelming congestion, had an average of $0.63 \mathrm{~m}$ of road per person. By 2013 the road length per person in the MMR had only increased to $0.40 \mathrm{~m}$ per person. If a city has such little road availability, it is physically impossible to accommodate a lot of traffic moving in space-consuming private vehicles. If the city 
is to remain functional, other modes must play a profound role, as even motorcycles reach limits of movement and parking space and frequently destroy walkability.

\subsection{Cars and Motorcycles}

Since 1996, car ownership in the MMR increased from a miniscule 21 cars per 1000 persons to only 68 cars per 1000 persons in 2014. Automobile megacities in 1995 had 482 cars per 1000 persons and even the traffic-saturated cities had 126 per 1000. By 2005 in US cities and 2006 in Australian cities there were 640 and 647 cars per 1000 persons respectively and European cities, 463 [12]. So, whilst the MMR increased 3.2 times in its car ownership in 18 years, it is still one of the lowest rates of car ownership in the world (e.g., Hong Kong in 2006 had 57 cars per 1000 persons, up from 46 in 1996).

In the face of growing though poorly distributed wealth, rapid motorization, limited road supply, and poor transit, the next best option to a car is a motorcycle and Indian cities are renowned worldwide as home to millions of 2-wheeler motorised vehicles. In 1996, motorcycles in the MMR stood at 32 motorcycles per 1000 persons, but by 2014 the ownership rate was 123, or 3.8 times higher. There are millions of people who still cannot afford a car (or for whom a car would be ineffective for many trips, because of the lack of road space), but who can afford a small scooter, which is easier to maneuver in traffic and much simpler to park (though generally at the expense of movement space for non-motorised modes).

\subsection{Wealth (GDP Per Person of the Metropolitan Region)}

All of the figures below are standardized for comparative purposes to a common basis of 1995 US dollars. The MMR significantly increased in wealth from a GDP per person of only \$913 in 1996 to $\$ 4194$ in 2012, a 4.6 times increase. Nevertheless, on a global scale, this is still relatively modest. In 1995, the average GDP per capita for the NMM cities was $\$ 2003$. In 2005, US cities averaged $\$ 44,445$ [5], or over ten times more than the MMR, while the poorest of the wealthy cities in the update sample (Hong Kong and Singapore) averaged \$21,201, or about five times higher than Mumbai. Such a low level of wealth also tends in the direction of less car and motorcycle use and favours cheaper NMM and transit modes.

\subsection{Transit Use}

The transit system in the MMR consists of:

Mumbai Metro (opened on 8 June 2014)

Mumbai Suburban Railways

Mumbai Monorail (opened on 2 February 2014)

BEST (buses) - this is the dominant provider in the region

NAVI Mumbai Municipal transport (buses)

Kalyan Dombivali Municipal Transport (buses)

Thane Municipal Transport (buses)

Mira-Bhayandar Municipal Transport (buses)

Vasai-Virar Municipal Transport (buses)

Recent data on these modes and operators gives a total of some 5,005,536,000 boardings per year or 232 per capita, modestly up from 225 in 1996. This consists of 105 boardings on buses and 127 on all of the rail modes combined. Such transit use is modest for a city of Mumbai's size and density. The New York metropolitan region (20 million people) had a density of only 19.2 persons per ha (6\% that of Mumbai's density) and 168 annual boardings per capita in 2005.

Commonly circulated images of people hanging from trains and jammed into buses in Mumbai suggest a transit system that has seriously exceeded its design capacity. The data suggest that it is barely able to hold its own and that it is probably quite remarkable that it increased slightly in per capita use. Further increases in transit use are limited in Mumbai by a lack of capacity, which in turn relates to issues of policy, finance, and governance in Indian cities generally. 
So, what is the present transport situation in the MMR? This is best summed up in the modal split for all trip purposes in the region. Such figures are hard to get as the surveys used to comprehensively obtain them are irregularly carried out due to high cost and complexity. The latest survey for the MMR was for 2006 [44].

\subsection{Modal Split for All Daily Trips}

In 2006, the average MMR resident made 1.20 daily trips when compared 1.30 in 1996, a small decrease. The 2006 data show that the MMR had $60.3 \%$ of all trips by NMM, 31.9\% by transit and a tiny $7.8 \%$ by private motorised modes. Of the NMM, $59.1 \%$ is walking and only $1.2 \%$ is bike. In 1996, the same figures were $49.8 \% \mathrm{NMM}, 40.9 \%$ transit and $9.3 \%$ private motorised modes. Ten years on from 1996, rather than weakening, the NMM contribution to daily trip-making had increased, while public and private transport modal share had dropped, possibly for the reasons already discussed (overcrowded transit and congested, slow traffic). If one excludes walking trips, transit dominates with $78 \%$ of all non-walking trips, while bikes account for only $3 \%$ and private motorised modes $19 \%$ of mechanized trips.

This latest mobility study also showed that more than $40 \%$ of workers in the MMR walk to their place of work, a possibly unique achievement in the 2000s for a metropolis the size of Mumbai. It further highlights the dense, mixed land use pattern, low incomes, and a paucity of other mobility options.

\subsection{Conclusions for Mumbai}

Mumbai, at least until 2006 and possibly later, has remained a Non-Motorised Mode city. Although cars and motorcycles have increased along with wealth and the road situation has reached chaos levels, the density of the region is still amongst the highest in the world (315 persons per ha) with intensively mixed land uses in most areas. The transit system suffers severe capacity problems, just like the roads, so the only possibility, or indeed sensible avenue for many trips, is to walk or use a bike or auto-rickshaw. Of course, the region is big and walking and other NMMs are only possible over relatively short distances. But for many peoples' daily needs, non-motorised transport is still plausible, though bikes at only $1.2 \%$ of all daily trips, need to be expanded by improving their operating conditions and safety.

Mumbai needs to improve and expand its rail-based transit modes, protect and renew its overstretched bus systems, and enhance the safety and convenience of pedestrians and other NMM use to protect and grow their share. The private transport alternative of trying to expand roads and parking is clearly not a viable proposition in such an extraordinarily dense urban region.

\section{Shanghai}

\subsection{Key Data}

The key data for Shanghai are included in Table 6.

\subsection{Urban Density}

Apart from Hong Kong (320 persons per ha), Shanghai in 1995 was the densest of the four mainland Chinese cities analysed by Kenworthy and Laube [12]. Shanghai's density was 196 persons per ha as compared to Beijing at 123 and Guangzhou at 119 (Taipei was 230 per ha). In 1995, the population of the defined metro region was 9,570,000, while in 2013 it was 14,319,000, evidence of the extreme urban growth in China. By 2009, under these growth pressures and expansion of the metropolitan area, the urban density of Shanghai declined to 170 per ha. This is still an extremely high density, which, in combination with the metro system, has grown from a mere $4.4 \mathrm{~km}$ in May 1993 (extended to $16.1 \mathrm{~km}$ by April 1995) to $588 \mathrm{~km}$ in 2015 with 364 stations, ensures that the city is far from being automobile dependent. 
Table 6. Key variables for the Shanghai Metropolitan Region in 1995 and recently.

\begin{tabular}{lccc}
\hline \multicolumn{1}{c}{ Urban Transport Indicators } & $\mathbf{1 9 9 5}$ & Recent & Year \\
\hline Key Transport and Land Use Variables & & & \\
\hline GDP per capita (USD 1995) & $\$ 2474$ & $\$ 7530$ & 2009 \\
Urban density (persons per ha) & 196.3 & 170.0 & 2009 \\
Length of road per person (m) & 0.31 & 1.22 & 2013 \\
Length of freeway per person (m) & 0.003 & 0.057 & 2013 \\
Passenger cars per 1000 persons & 15.2 & 144.7 & 2013 \\
Motorcycles per 1000 persons & 44.0 & 29.0 & 2013 \\
Total transit boardings per person & 452.9 & 411.4 & 2014 \\
- Bus boardings per person & 452.9 & 197.5 & 2014 \\
- Rail boardings per person & 0.0 & 209.6 & 2014 \\
- Ferry boardings per person & 0.0 & 4.3 & 2014 \\
\hline Modal Split for Total Daily Trips & & & \\
\hline Daily trips by non-motorised modes & $77.9 \%$ & $54.8 \%$ & 2009 \\
Daily trips by motorised public modes & $15.1 \%$ & $25.2 \%$ & 2009 \\
Daily trips by motorised private modes & $7.0 \%$ & $20.0 \%$ & 2009 \\
\hline Modal Split for Mechanised Total Daily Trips & \multicolumn{3}{c}{} \\
\hline Daily trips by mechanised, non-motorised modes & $67.1 \%$ & $38.8 \%$ & 2009 \\
Daily trips by motorised public modes & $22.5 \%$ & $34.1 \%$ & 2009 \\
Daily trips by motorised private modes & $10.4 \%$ & $27.1 \%$ & 2009 \\
\hline
\end{tabular}

Note: Although for 1995, the Shanghai metro system was in operation, its annual boardings (on only $4.4 \mathrm{~km}$ for 4 months and $16.1 \mathrm{~km}$ of route length for 8 months), were only 230,000 or an unmeasurable 0.024 boardings per person. This does not even figure to one decimal point and therefore it was not included in the 1995 data.

\subsection{Road Supply}

In 1995, Shanghai, like Mumbai, had a tiny supply of roads (0.31 m per person). By 2013, unlike Mumbai, Shanghai's road supply had quadrupled to $1.22 \mathrm{~m}$ per person. In addition, the supply of freeways had grown from $0.003 \mathrm{~m}$ per person to 0.057 per person (a 19-times increase). The difference seems to be that Shanghai is far more organized and well-resourced than Mumbai in developing all forms of transport infrastructure, so the differences between the cities in 1995 have now widened. Shanghai has transformed itself since the onset of motorisation.

\subsection{Cars and Motorcycles}

Shanghai also distinguishes itself from Mumbai in its significantly greater increase in the car fleet. In 1995, Shanghai had a mere 15 cars per 1000 persons. By 2013, this had multiplied 9.5 times to 145 cars per 1000 persons. This is still very low car ownership, though it now significantly exceeds Singapore in 2005 with 100 cars per 1000 persons. Singapore is a much wealthier city than Shanghai, but Singapore has controlled car ownership since the 1970s through financial imposts [45]. Hong Kong, in 2005, averaged only 57 cars per 1000 persons, while US cities averaged 640 per 1000 persons, Australian 647, and European cities 463.

Shanghai, however, has developed differently to Mumbai in motorcycles. In 1995, motorcycles stood at 44 per 1000 persons, but this reduced to 29 per 1000 persons by 2013. The total number of motorcycles in Shanghai reached a peak in $2004(1,135,000)$, but from that year the numbers declined to 425,100 (2014). This is common to all three mainland Chinese city case studies here, where motorcycles are playing a diminishing role, a trend that is counter to what is happening in most other world cities [5]. 


\subsection{Wealth (GDP per Person)}

Shanghai is noticeably wealthier than Mumbai and its GDP per capita increased from \$2474 in 1995 to $\$ 7530$ in 2009 (USD 1995), though by comparison to wealthier cities it is still very low (e.g., a large sample of European cities averaged \$38,683 in 2005-[5]).

\subsection{Transit Use}

The transit system in Shanghai consists of an extensive metro system, now the longest in the world $(588 \mathrm{~km})$, all opened in the space of 22 years from 1993, plus a very extensive bus and trolley bus system and a small ferry service. In 1995, there were 453 boardings per person (buses) while in 2014 total transit boardings had fallen to 411 per person. With rapid deployment of the metro system, buses have played a declining role in transit (and perhaps would have without the metro because they cannot compete in speed terms). The metro by 2014 had almost regained the declining bus system use, which is a significant feat when considering that car ownership has multiplied almost 10-fold over the same period.

Notwithstanding competition from private motorised modes, the metro together with an improving and extensive bus system (some 15,500 buses and 700 trolley buses), are beginning to transform Shanghai into a "transit metropolis" [46].

\subsection{Modal Split for All Daily Trips}

In 1995, Shanghai was an extraordinary NMM city of nearly 10 million people, having some $78 \%$ of all daily trips by foot or bike, another $15 \%$ by transit, and a meager $7 \%$ by private motorised modes. By 2009, the latest comprehensive data available, NMM had declined, but to a still very healthy $55 \%$ of daily trips. This loss of NMM usage was picked up with a significant growth in transit's share, up from $15 \%$ to $25 \%$ in 2009. Naturally, a big growth area was private motorised modes, which by 2009 was $20 \%$. Whilst this represents almost a tripling of private mode share, it is very small. However, in such a dense setting, cars and motorcycles have a radical effect on public environments, including congestion, despoiled public spaces, air pollution and noise. In 1995 only seven cities out of 100 in Kenworthy and Laube [12] had such a low level of private mode use (Guangzhou: 16.5\%, Hong Kong: 18.5\%, Manila: $19.6 \%$, Chennai: $13.8 \%$, Tunis: $19.9 \%$, Mumbai: $9.3 \%$, and Dakar: $18.3 \%$ ). For such a large city, under so much development pressure and rapidly increasing in prosperity, to have still only $20 \%$ private mode use, is a significant achievement. This is partly due to the Singapore-style auction system for car ownership in Shanghai [47].

\subsection{Conclusions for Shanghai}

Shanghai has clearly not become an Auto City, a Hybrid City, a Paratransit City, or even a Traffic-Saturated City, as in Table 4. This means we must ask if it is still a NMM city or has it evolved into a Transit City? With 55\% of daily trips by NMM (average for an NMM city: 61\%), on this single factor it still has clear NMM credentials and is much better than the Transit Cities (only 26\% NMM). Shanghai's transit modal split is also $25 \%$, which is the same as the NMM cluster, though its per capita use of transit today is significantly higher than in the NMM cities in 1995. Shanghai's density is almost the same as the Transit Cities in 1995. Length of road per capita, freeway provision, and car ownership are also not dissimilar to the Transit Cities in 1995. Shanghai, however, had a radically lower GDP per capita in 2009 than the Transit Cities in 1995.

The most plausible conclusion is that Shanghai has become more like a Transit City, but has achieved this very much faster and at a very much earlier stage in the economic development cycle, most likely due to the significant economic boom of China and its ability to invest vast sums of money in rail [47]. On the other hand, Shanghai could also be considered as a Transit City that maintains a very high level of NMM use, due partly at least to the heritage and culture associated with these modes in a very dense and mixed-use environment. If the cluster analysis was to be repeated today, 
it might be that Shanghai and some other Chinese cities, could form a new cluster (perhaps 'Emerging Transit Cities', as opposed to mature Transit Cities such as Tokyo or Osaka).

\section{Beijing}

\subsection{Key Data}

Beijing, the capital of the Peoples' Republic of China (PRC) has undergone major changes since 1995. In 1995, the population of the defined metropolitan area (10 districts) was $8,164,000$ people and in 2012, the latest year for corresponding land use data, it had increased to 13,561,000, a growth of 5.4 million people. The metropolitan area of Beijing in 2012 was 20,132,000 people due to rapid expansion of this national economic engine. The standardized data in Table 7 have been calculated to ensure the correct populations are used with each item. Table 7 captures some major changes in land use and transport over this period of strong growth.

Table 7. Key variables for the Beijing Metropolitan Region in 1995 and recently.

\begin{tabular}{lccc}
\hline \multicolumn{1}{c}{ Urban Transport Indicators } & $\mathbf{1 9 9 5}$ & Recent & Year \\
\hline Key Transport and Land Use Variables & & & \\
\hline GDP per capita (USD 1995) & $\$ 1829$ & $\$ 9850$ & 2012 \\
Urban density (persons per ha) & 123.1 & 102.0 & 2012 \\
Length of road per person (m) & 0.32 & na & - \\
Length of freeway per person (m) & 0.005 & 0.046 & 2012 \\
Passenger cars per 1000 persons & 42.9 & 230.9 & 2012 \\
Motorcycles per 1000 persons & 27.7 & 15.6 & 2012 \\
Car vehicle kilometres per person (VKT) & 785 & 3017 & 2012 \\
Total transit boardings per person & 456.7 & 408.6 & 2014 \\
- Bus boardings per person & 386.8 & 239.2 & 2014 \\
- Rail boardings per person & 68.4 & 169.4 & 2014 \\
\hline Modal Split for Total Daily Trips & & & \\
\hline Daily trips by non-motorised modes (\%) & $47.9 \%$ & $21.8 \%$ & 2012 \\
Daily trips by motorised public modes (\%) & $27.8 \%$ & $39.8 \%$ & 2012 \\
Daily trips by motorised private modes (\%) & $24.3 \%$ & $38.3 \%$ & 2012 \\
\hline Modal Split for Mechanised Total Daily Trips & & & \\
\hline Daily trips by mechanised, non-motorised modes (\%) & $42.6 \%$ & $13.9 \%$ & 2012 \\
Daily trips by motorised public modes (\%) & $30.7 \%$ & $44.0 \%$ & 2012 \\
Daily trips by motorised private modes (\%) & $26.7 \%$ & $42.1 \%$ & 2012 \\
\hline
\end{tabular}

Note: Beijing strangely does not report walking trips in its modal split anymore. However, in 1995 walking trips comprised $9 \%$ of the $47.9 \%$ NMM split. Fully $39 \%$ of the trips were by bike and it is bikes that have been decimated. Based on the dramatic trend down in bikes and the apparent small use of walking modes in 1995, plus the other trends from 1995 to 2012 in all the other modes, I have made a supportable estimate of the full modal split for 2012 including walking. Thus, the first set of modal split data in Table 7 for 2012 are estimates based on real data, while the second set are actual data.

\subsection{Urban Density}

Beijing, in 1995, had a much lower urban density than Shanghai (123 per ha versus 196 per ha), and like Shanghai, it has reduced in density since then, as the outward forces of growth at lower densities has reduced the average density by $17 \%$ (cf. Shanghai $-13 \%$ ). Despite this change, Beijing is still high density (102/ha) and not anything like the low densities of the Hybrid or the Auto Cities megacity (35 per ha and 21 per ha: Table 4). This decrease in density, along with the other changes, has pushed Beijing towards greater reliance on private motorised modes of transport. 


\subsection{Road Supply}

The length of all road types in Beijing was not available, but total road supply is highly correlated with urban density (every property must have basic road access so as density declines, the road length needed to service it increases). It is likely that road supply has increased like in Shanghai and maybe even more, due to Beijing's rapid freeway construction (e.g., seven freeway Ring Roads constructed over the last 20 years).

Freeway length increased from a modest $42 \mathrm{~km}$ in 1995 to $922 \mathrm{~km}$ in 2012, a 22-fold increase in 17 years. Per capita freeway length increased a little over nine times from $0.005 \mathrm{~m}$ per person to $0.046 \mathrm{~m}$ per person, like Shanghai. Freeways have proven over decades to facilitate more traffic, so Beijing is unlikely to be an exception in this [37].

\subsection{Cars and Motorcycles}

Until a few years ago, Beijing promoted private motor vehicles, unlike Shanghai, which adopted early restraint of car ownership through an auction system like Singapore's Certificate of Entitlement. Shanghai's system started in 1986 but was only in full operation by 2000 [41,48]. Beijing had to slow down motor vehicle growth due to congestion, globally publicized air pollution problems, and excessive land consumption for sprawling auto-oriented growth. The Beijing Olympics in 2008 emphasized this need for change. Effective January 2011, Beijing introduced a lottery system to limit the monthly number of new car registrations. However, the differences can be seen: Beijing in 2012 had 231 cars per 1000 persons, compared to Shanghai with 145 per 1000. Growth in car numbers, more than any other single factor, has been behind the increase traffic in Chinese cities (see below).

Like Shanghai, motorcycles per 1000 persons has reduced. In Beijing, in 2012, there were 16 motorcycles per 1000 persons compared to 29 per 1000 in Shanghai. Electric motorcycles have been encouraged and ICE (Internal Combustion Engine) motorcycles discouraged, which may help to explain the decline. The low number of motorcycles is quite unusual for Asian cities, and increasingly in the world, as people in congested cities seek a private mobility solution that is more easily able to cope with stalled traffic. That both Beijing and Shanghai have radically improved their transit systems, especially metro systems, may also explain the lower number of motorcycles; they are less needed because fast travel speeds are possible on transit.

\subsection{Wealth (GDP per Person)}

Given the Chinese economy over recent years, Beijing's GDP per capita has greatly increased from $\$ 1829$ to $\$ 9850$ per capita (USD 1995), 5.4 times increase. This also encourages more private transport, but where good transit systems are provided, it also improves peoples' ability to pay for quality transit such as new metro systems, which has happened in both Shanghai and Beijing.

\subsection{Transit Use}

Transit in Beijing is critically important, especially the metro, but also the extensive and effective bus system. In 1969, when Beijing's metro opened, it had a route length of $21 \mathrm{~km}$. Today it has eighteen lines with 334 stations and $554 \mathrm{~km}$ of route, the second biggest in the world and mostly built since 2003.

Transit boardings per person in 1995 were 457, declining to 409 in 2014, a reduction over 17 years of about $10 \%$. Rail boardings have grown a lot but bus boardings have declined considerably. Considering Beijing's wealth and car ownership have multiplied some five times and its freeway system has expanded some twenty-two times, this level of transit use is very commendable. For example, European cities in 2005 averaged 386 boardings per person, while the two mature transit metropolises of Singapore and Hong Kong averaged 450 [5].

Beijing is rapidly evolving into one of the world's major transit metropolises. The metro system continues to grow rapidly with an expected $1000 \mathrm{~km}$ network by 2020 [47]. This, combined with the 
lottery-based controls on car ownership that have been in place since 2011, it is difficult to imagine Beijing moving in any other direction than a transit city.

\subsection{Modal Split for All Daily Trips}

Beijing has lost a lot of mode share from NMM. Bikes have declined from $62.7 \%$ of all trips (excluding walk trips) in 1986, to $13.9 \%$ in 2012. This is a decimation in bikes resulting in a halving of the modal split for NMM for all trips between 1995 and 2012 (47.9 to 21.8\%) (bearing in mind the footnote for Table 7). However, more positively, for trips excluding walking, transit has increased from 30.7 to $44.0 \%$ of trips and including walking trips, transit has a $40 \%$ share. Private motorised modes (cars and motorcycles) only accounted for $38 \%$ of all trips and $42 \%$, excluding walking. Again, Beijing is far from being an automobile dependent region.

\subsection{Car Use}

Total annual travel by cars has increased significantly, from $785 \mathrm{~km}$ per person to just over $3000 \mathrm{~km}$, a 3.8-fold increase, though not as large as the increase in wealth or car ownership (5.4 times). Beijing's use of cars is significantly below the European cities, (just under $5000 \mathrm{~km}$ per person) and a fraction of US cities (13,100 km). Beijing has above the average Transit City car kilometres per capita in Table 4 $(2083 \mathrm{~km})$, but this average for the Transit Cities is likely to have increased somewhat too over 17 years.

\subsection{Conclusions for Beijing}

From available evidence, Beijing probably moved out of the NMM cluster and into the Transit City cluster, or alternatively, like Shanghai, it might fit into a new cluster (Emerging Transit Cities). Beijing's 2012 characteristics are more like a Transit City than any other cluster and with the continued development of the Beijing Metro and the relatively recent controls over car ownership, one might expect Beijing to strengthen its position as a Transit City.

\section{Guangzhou}

\subsection{Key Data}

Guangzhou was the smallest of the three Chinese cities in 1995, with 3,853,800 people. The region in 2012 had a population of 12,838,900. The equivalent metro area in 1995 had a 2012 population of $8,168,400$. In 2014 , the population for the whole region was $13,080,500$, so it is a very rapidly growing metro area in China, due partly to its links and proximity to Hong Kong. However, it was also the wealthiest and the lowest density of the four Chinese cities in this paper. In 1995, it had no rail system (Shanghai had just opened its first line, while Beijing had run a metro since 1969) and had no freeways. Table 8 captures key changes in Guangzhou from 1995 to 2008 or 2014, depending on the variable.

\subsection{Urban Density}

Guangzhou was the lowest density of the four Chinese cities at 119 persons per ha (1995). Since then, it has expanded outwards and the population has grown by 9 million people. This is major urban change in just 19 years, like some other exceptional Chinese urbanization stories (e.g., Shenzen). Guangzhou's density had fallen to 100 persons per ha by 2012 (16\% decline and approximating the percentage fall in density in the other two mainland Chinese cities), but this is still comparatively high.

\subsection{Road Supply}

Guangzhou had a little more road availability in 1995 (0.47 m per person) than the other three Chinese cities, and this grew to $0.70 \mathrm{~m}$ per person by 2014 . However, this is extremely low road provision globally and is in keeping with Guangzhou's high density in 2014.

Guangzhou had no freeways in 1995 but by 2014 it had built $852 \mathrm{~km}(0.065 \mathrm{~m}$ per person). By 2014, Guangzhou had over three times more freeway provision per capita than the Transit Cities (Table 4), 
and the highest of all four Chinese cities. This represents rapid freeway construction from 1995 to 2014, in line with Chinese motorisation over the period.

Table 8. Key variables for the Guangzhou Metropolitan Region in 1995 and recently.

\begin{tabular}{lccc}
\hline \multicolumn{1}{c}{ Urban Transport Indicators } & $\mathbf{1 9 9 5}$ & Recent & Year \\
\hline Key Transport and Land Use Variables & & & \\
\hline GDP per capita (USD 1995) & $\$ 2796$ & $\$ 11,929$ & 2012 \\
Urban density (persons per ha) & 119.0 & 100.2 & 2014 \\
Length of road per person (m) & 0.47 & 0.70 & 2014 \\
Length of freeway per person (m) & 0.000 & 0.065 & 2014 \\
Passenger cars per 1000 persons & 20.2 & 147.0 & 2014 \\
Motorcycles per 1000 persons & 93.7 & 19.8 & 2014 \\
Car vehicle kilometres per person (VKT) & 337 & na & - \\
Total transit boardings per person & 215.1 & 400.9 & 2012 \\
- Bus boardings per person & 196.7 & 234.7 & 2012 \\
- Rail boardings per person & 0.0 & 164.3 & 2012 \\
- Ferry boardings per person & 18.3 & 1.9 & 2012 \\
\hline Modal Split for Total Daily Trips & & & \\
\hline Daily trips by non-motorised modes (\%) & $69.3 \%$ & $42.2 \%$ & 2008 \\
Daily trips by motorised public modes (\%) & $14.2 \%$ & $34.3 \%$ & 2008 \\
Daily trips by motorised private modes (\%) & $16.5 \%$ & $23.5 \%$ & 2008 \\
\hline Modal Split for Mechanised Total Daily Trips & & & \\
\hline Daily trips by mechanized, NMM (\%) & $52.8 \%$ & $12.4 \%$ & 2008 \\
Daily trips by motorised public modes (\%) & $21.8 \%$ & $52.0 \%$ & 2008 \\
Daily trips by motorised private modes (\%) & $25.3 \%$ & $35.6 \%$ & 2008 \\
\hline
\end{tabular}

\subsection{Cars and Motorcycles}

In 1995, Guangzhou had only 20 cars per 1000 people, but by 2014 it had 147, a 7.3 times increase. Motorcycles, however, declined from a relatively high level of 94 to 20 per 1000 persons between 1995 and 2014, in common with Shanghai and Beijing. Motorcycle numbers peaked in $2003(1,120,000)$, declining to only 258,980 in 2014.

\subsection{Wealth (GDP per Person)}

Guangzhou was the wealthiest of the three mainland Chinese cities in 1995, and has continued with this distinction. It grew from $\$ 2796$ to $\$ 11,929$ in 2012 (USD 1995), a 4.3-fold increase. As with all the Chinese cities, this increase in wealth facilitates private transport, but can also promote transit use where good systems are provided to meet growing demands and expectations.

\subsection{Transit Use}

Guangzhou's metro opened later (1997) than in the other three Chinese cities. Since then, it has increased to $268 \mathrm{~km}$ with nine lines and 167 stations and many new lines and extensions are currently under construction, approved or proposed.

Guangzhou's transit boardings per person (215) in 1995 were relatively poor as compared to Shanghai and Beijing. However, by 2012 it had radically increased to 401. Unlike in the other three Chinese cities, bus usage has grown alongside the large jump from zero to 164 rail boardings per person. The three Mainland Chinese cities now have very similar total transit use per person (Guangzhou 401, Beijing 409, and Shanghai 411 boardings per capita). Guangzhou's transit performance is quite exemplary, considering the large increase in cars, the big increase in wealth, the huge increase in freeways and the moderate decline in density. 


\subsection{Modal Split for All Daily Trips}

Urban mobility in Guangzhou has undergone some radical changes between 1995 and 2008 (latest data available). Non-motorised transport suffered a significant decline from $69 \%$ of daily trips down to $42 \%$. But when compared to Beijing and other cities, this level of non-motorised mobility is very large. It is hard to say if this has continued to decline at the same rate as from 1995 to 2008, or whether the decline has stabilized, or accelerated. Coming from such a high base, it is likely that NMMs are still significant.

The big success story in Guangzhou is, however, transit. Not only have transit boardings per person taken a huge upturn, the modal split for transit has increased from 14 to $34 \%$ in 2008, almost a 2.5 times increase (and this is 2008 data when transit boardings in the city were much lower than in 2012). By 2008, private motorised modes in Guangzhou had only increased from 16 to $23 \%$, thus $77 \%$ of all daily trips were still by NMM and transit.

\subsection{Conclusions for Guangzhou}

Guangzhou is far from being automobile dependent, even though motorisation has proceeded apace between 1995 and 2014. It still retains very significant NMM usage and healthy transit use, with a rapidly expanding metro system and a successful BRT system [49]. Its transit growth has been one of the factors that has tamed the expansion of private motorised traffic, such that private motorised modes represented in 2008 only $23 \%$ of all daily trips. Even allowing for further expansion of private motorised traffic beyond 2008, one could surmise that these modes might account for not more than about one-third of all daily trips.

Like Shanghai and Beijing, the only logical group into which Guangzhou may have moved is the Transit City cluster. Again, it might be termed an "Emerging Transit City". Its key characteristics are most like the Transit City cluster. With continued plans for metro extensions and accompanying BRT and bus integration, as well as car registration restrictions introduced in June 2012 (effective until July 2018) [48], it seems likely that Guangzhou will continue to strengthen its Transit City credentials. Guangzhou's car registration restrictions are like those in Singapore and Shanghai, based on a monthly auction, but also partly on a lottery system as in Beijing

\section{Discussion}

These case studies of cities that are all experiencing rapid motorisation and perhaps appear to be capitulating to the automobile through the picture portrayed by congestion and the sheer presence and impact of cars and motorcycles, present a different perspective when examined at an urban system level through a wide variety of data. Certainly, none of them appear in any way near to, or even capable of, progressing close to typical auto city levels of car dependence. In fact, physical limits are already being reached that make higher levels of private motorised mobility very problematic if the transport system is to remain functional. Similar conclusions and processes have been evident in Bangkok [50,51] and other less developed cities [52]. These limits appear already to be creating a turnaround or stabilisation in the usage of non-motorised modes and an upturn in transit, especially rail. That these cities have been able to either hold their own, or somewhat increase their share of total motorised mobility by transit over a 10 to 15 -year period, is some indication that they are all hitting private mobility walls much sooner in the motorisation path than cities in North America and Australia, which grew up with and were designed around the space needs of cars.

Many cities in the developed world have shown a decoupling of car use and total passenger mobility from GDP growth between 1995 and 2005 [26], and the same is proving true for these much less wealthy cities. This is important because global and local goals for reduced $\mathrm{CO}_{2}$ from urban passenger transport can be met without affecting needed economic progress.

It is very important for policymakers in cities of emerging economies to realise the already positive patterns and not to assume that they are fighting a losing battle with motorisation (e.g., [53] and 
especially Chapter 3 on China). It gives hope and initiative to transport policymaking to realise that automobile dependence, far from being the "irresistible force" it has always been cast as [17], is rather something that can and is being reversed. Whilst not underestimating that public environments, congestion, and city livability can and possibly will get worse in such cities, while more vehicles are squeezed into confined spaces, motorisation in a longer perspective may be losing the battle (while still generating a lot of smoke and battle scars in the process). It appears impossible to find an accommodation with the mass use of automobiles and motorcycles that allows such dense cities to remain both functional and livable. Once this physical limit is realised, and that cities are already adjusting and reversing motorisation, perhaps even "under the radar" urban policy can assist and accelerate the process.

Of course, the cities presented in this paper represent a wide range of institutional and cultural contexts, which in turn affect the ability of cities to respond to transport pressures through their varied urban governance capabilities. The cities in China have the benefit of reasonably strong urban planning and transport policy frameworks [54], as well as a dynamic national economy that allow for change to be implemented and funded rather rapidly-witness the massive growth in urban rail systems over the last 25 years [47]. The question of the role of different urban governance frameworks in urban transport and how these affect responses to motorization and automobile dependence generally in emerging economies, is beyond the scope of this paper. However, its importance can be gleaned in, for example, Rode [55], Barter and Dotson [56], and Thi Phin and Dotson [57] in their discussions of London, Berlin, Singapore, and Hanoi.

In summary, it is possible to see the demise of any trend towards automobile dependence in currently motorising cities, and much faster than perhaps anyone may have thought possible.

The case studies of Mumbai, Shanghai, Beijing, and Guangzhou permit an additional insight into the above processes. Using 1995 data, these four cities formed one of six clusters, the Non-Motorised Mode cities, the other five clusters being Transit, Paratransit, Traffic-Saturated, Hybrid, and Auto Cities. Since 1995, many things have happened in cities concerning mobility, including peak car use in many developed cities and the decoupling of GDP growth from car use [5,26]. Many cities in emerging economies are rethinking their trajectories for the future and are choosing to install extensive new transit systems (both rail and BRT), limiting car ownership and use and protecting their urban environments to increase peoples' use of NMM. Many are also trying to build new dense, mixed-use developments around transit to factor in less car and motorcycle dependence in the future.

In short, the glamour of the automobile in dense, space, and road-constrained cities has lost much of its shine and numerous cities are shifting to polycentric forms served better by transit and NMM, and which are practicing at least some forms of control over the car. The Chinese cities, after about 15 years of strongly embracing the automobile have, since around 2011, begun to moderate this stance, especially in the megacities. Because of this, it can be argued that the 1995 cluster analysis might produce different results for such cities today and might reveal the existence of new clusters of cities that did not exist in 1995. One such possibility might be Emerging Transit Cities, in contrast to 'mature' Transit Cities such as Tokyo, Osaka, or Hong Kong, which decades ago established themselves firmly as "transit giants". Barter [18,19] pre-figured such a transition in his research on Asian cities and their possible transport trajectories.

The main characteristics of an Emerging Transit City, based on the trajectory of the Chinese cities, would be:

- Development of extensive rail systems early in the economic development cycle and over a relatively short period of time, i.e., they still have comparatively low, though rapidly growing GDP per capita.

- Continued high-density land use patterns, exceeding 100 persons per ha.

- Implementation of some control over car ownership and use, as Singapore did starting in the 1970s. This control follows periods of rapid growth in cars, which was found to be unsustainable for a wide variety of reasons. 
- Significant levels of NMM use, notwithstanding early, often large reductions. NMM in most cases are beginning to make a small comeback in terms of usage.

- High per capita transit use (boardings and PKT per person) by world standards (generally exceeding 400 annual boardings per person and growing). Transit use will exceed even that of the European cities in the mid-2000s.

- Transit accounts for at least around 35\% of all daily trips (all modes), a figure that will likely grow due to the continued rapid expansion of metro systems.

- Still comparatively low per capita VKT in cars.

- Private motorised modes play a lesser role in the overall transport system than transit and NMM combined, accounting for between $25 \%$ and $40 \%$ of total daily trips.

- Car ownership would be generally less than 250 cars per 1000 persons.

In terms of the future evolution of such cities, a possible prognosis based on recent patterns might be:

- continued per capita growth in transit use;

- continued rapid development in wealth;

- upturn or stabilization in the decline of NMM use;

- slowing down in growth of cars and car use;

- slowing down in growth of freeways;

- stabilization or reversal in growth of modal split for private motorised modes; and,

- longer term trajectory towards a Mature Transit City with healthy NMM use.

\section{Conclusions and Policy Implications}

Automobile dependence in the mostly dense, mixed land use cities of emerging economies is not an irresistible force, though the effectiveness of responses to it will depend at least partially on urban governance capabilities. This paper, however, has highlighted certain physical or in-built limitations on how far automobile dependence can proceed in the cities of emerging economies and how this may be promoting and facilitating at least some positive urban change.

Data perspectives over 15 to 20 years reveal many positive changes in the transport systems in seven cities in Europe, Latin America, China, and India, and suggest a different possible future for such cities, including in some cases, their evolution into emerging transit cities with high use of NMM. Such cities generally do not have a problem with low density. Rather, there is a mismatch between their high density, mixed use forms and their transport infrastructure. This fact and other findings from the research point to some key policy needs in these cities, as follows:

(1) strengthen the extent, quality, and operational speeds of urban transit systems, especially rail and particularly in relation to average roads speeds;

(2) protect and enhance bus modes through dedicated bus lanes/BRT systems, but with a recognition that bus capacity and bus speed competitiveness with private transport modes, even with BRT, has limits that can then only be solved by rail systems;

(3) significantly improve the conditions for non-motorised modes, such as through fairer space allocation, better systems for crossing streets (current pedestrian bridges in many cities unfairly disadvantage pedestrians in favour of smoother flowing traffic), as well as greater safety and protection for vulnerable users of these modes. Many cities have seen the benefits of allocating more space to pedestrians and cyclists through pedestrianisation and traffic calming schemes and just simple and enforceable bike lane allocation on busy roads [58-60];

(4) limit car and motorcycle ownership and use through physical and financial means (such as in Singapore and now numerous Chinese cities), and introduce some forms of wider congestion control through perhaps road pricing, carbon taxes or "congestion offsets" [31]; 
(5) ensure that new development in areas far from the centre are linked effectively to transit and that medium to high densities and mixed land uses are maintained, especially within around a $1 \mathrm{~km}$ radius of rail or BRT stations (as well as protection of the public realm in such areas to facilitate easy and safe non-motorised and transit feeder access to stations);

(6) generally maximise the integration of transport and land use development through more effective urban policy and linkages between planning, transport, and traffic institutions;

(7) limit the creation of new urban land from farmland or natural environments. This will not only have transport benefits, but also wider sustainability benefits through more green space and local food production (less "food miles"); and,

(8) strictly limit the construction of new, high capacity roads, be they genuine freeways or tollways. Such roads always increase private motorised mode use.

Further research on all these topics in cities in emerging economies is needed. As well, a much larger sample of cities is required to examine the key variables investigated in this paper to see if similar or contrary patterns are found. Finally, there is a need to progressively track such changes, and for this, systematic new data must be continually obtained, processed, and compared on a consistent basis. It is difficult to maintain the currency of this type of research unless more funding can be found to carry out longitudinal studies on a continuous basis, as opposed to snapshots in time.

Acknowledgments: The author acknowledges the important support of Yuan Gao at Curtin University whose work and translations using Chinese statistical resources were indispensable. The work of Monika Brunetti in the data preparation and management on Taipei, Prague and São Paulo and Ashish Verma in supplying the Mumbai data, are gratefully acknowledged.

Conflicts of Interest: The author declares no conflict of interest.

\section{References}

1. United States Environmental Protection Agency (USEPA). Air Pollution: Current and Future Challenges. 2017. Available online: https:/ / www.epa.gov/clean-air-act-overview/air-pollution-current-and-futurechallenges (accessed on 25 September 2017).

2. Kunstler, J.H. The Geography of Nowhere; Simon and Schuster, Touchstone: New York, NY, USA, 1993.

3. Newman, P.W.G.; Kenworthy, J.R. Cities and Automobile Dependence: An International Sourcebook; Gower: Aldershot, UK, 1989.

4. Newman, P.W.G.; Kenworthy, J.R. Sustainability and Cities: Overcoming Automobile Dependence; Island Press: Washington, DC, USA, 1999.

5. Newman, P.; Kenworthy, J. The End of Automobile Dependence: How Cities Are Moving Away from Car-Based Planning; Island Press: Washington, DC, USA, 2015.

6. Whitelegg, J. Mobility: A New Urban Design and Transport Planning Philosophy for a Sustainable Future; Straw Barnes Press: Church Stretton, UK, 2015. Available online: https:/ /www.amazon.com/Mobility-TransportPlanning-Philosophy-Sustainable-ebook / dp / B013H0ZYU0/ref=sr_1_1?ie=UTF8\&qid=1494576101\&sr=81\&keywords=Whitelegg (accessed on 25 September 2017).

7. Cervero, R. Transport Infrastructure and the Environment: Sustainable Mobility and Urbanism. In Proceedings of the 2nd Planocosmo International Conference, Bandung, Indonesia, 21-22 October 2013; Working Paper 2013-03; Institute of Urban and Regional Development, University of California: Berkeley, CA, USA, 2013.

8. UN Habitat. Global Report on Human Settlements 2011: Cities and Climate Change; UN Habitat: Nairobi, Kenya, 2011.

9. International Energy Agency (IEA). Key World Energy Statistics; IEA: Brussels, Belgium, 2011. Available online: http:/ /iea-gia.org/wp-content/uploads/2012/08/key_world_energy_stats-2011-27Dec11.pdf (accessed on 24 October 2017).

10. IFP Energies Nouvelles. IFP Energies Nouvelles Activity Report 2012; IFP Energies Nouvelles: Lyon, France, 2012. 
11. Kenworthy, J.; Laube, F.; Newman, P.; Barter, P.; Raad, T.; Poboon, C.; Guia, B. An International Sourcebook of Automobile Dependence in Cities 1960-1990; University Press of Colorado: Boulder, CO, USA, 1999.

12. Kenworthy, J.; Laube, F. The Millennium Cities Database for Sustainable Transport. (CDROM Database); International Union (Association) of Transit, (UITP); Brussels and Institute for Sustainability and Technology Policy (ISTP): Perth, Austria, 2001.

13. Perl, A.; Kenworthy, J. The Canadian City at a Crossroads between 'Passage' and 'Place'. In Canadian Cities in Transition; Bunting, T., Filion, P., Eds.; Oxford University Press: Oxford, UK, 2010; Chapter 11, pp. 191-209.

14. Raad, T.; Kenworthy, J.R. The US and Us. Alternatives 1998, 24, 14-22.

15. Schneider, K. On the Nature of Cities: Towards Creative and Enduring Human Environments; Jossey-Bass: San Francisco, CA, USA, 1979.

16. Schiller, P.L.; Kenworthy, J.R. An Introduction to Sustainable Transport: Policy, Planning and Implementation, 2nd ed.; Earthscan (Taylor and Francis/Routledge): London, UK, 2018.

17. Lave, C. Cars and demographics. Access 1992, 1, 4-11.

18. Barter, P.A. An International Comparative Perspective on Urban Transport and Urban Form in Pacific Asia: Responses to the Challenge of Motorisation in Dense Cities. Ph.D. Thesis, Murdoch University, Perth, Australia, 1999.

19. Barter, P.A. Urban transport in Asia: Problems and prospects for high-density cities. Asia-Pac. Dev. Monit. 2000, 2, 33-66.

20. Townsend, C. In Whose Interest? A Critical Approach to South East Asia's Urban Transport Dynamics. Ph.D. Thesis, Murdoch University, Perth, Australia, 2003.

21. Geels, F.W.; Kemp, R.; Dudley, G.; Lyons, G. (Eds.) Automobility in Transition: A Socio-Technical Analysis of Sustainable Transport; Routledge: New York, NY, USA, 2012.

22. Sengers, F. Transforming Transport in Thailand: Experimenting for Transitions to Sustainable Urban Mobility; Technische Universiteit Eindhoven: Eindhoven, The Netherlands, 2016.

23. Kenworthy, J.R. The Good, the Bad and the Ugly in Urban Transport: Comparing Global Cities for Dependence on the Automobile. In Methods for Sustainability Research; Hartz-Karp, J., Marinova, D., Eds.; Edward Elgar Publishing: Cheltenham, UK, 2017; Chapter 3, pp. 46-62.

24. Cabral, P. São Paulo: A City with 180 km Traffic Jams. BBC News, 25 September 2012. Available online: http:/ / www.bbc.com/news/magazine-19660765 (accessed on 18 September 2017).

25. Buehler, R.; Pucher, J.; Gerike, R.; Götschi, T. Reducing car dependence in the heart of Europe: Lessons from Germany, Austria, and Switzerland. Transp. Rev. 2016. [CrossRef]

26. Kenworthy, J. Decoupling urban car use and metropolitan GDP growth. World Transp. Policy Pract. 2013, 19, 7-21.

27. Dimitriou, H. Urban Transport Planning: A Developmental Approach; Originally Published 1992; Routledge Revivals: London, UK, 2013.

28. Marchetti, C. Anthropological invariants in travel behavior. Technol. Forecast. Soc. Chang. 1994, 47, 75-78. [CrossRef]

29. Newman, P.W.G.; Kenworthy, J.R. Urban Design and Automobile Dependence: How much development will make urban centers viable? Opolis 2006, 2, 35-52.

30. Serva, L. How São Paulo Uses "Value Capture" to Raise Billions for Infrastructure. Citiscope, 22 May 2014. Available online: http:/ /www.citiscope.org/story/2014/how-São-paulo-uses-value-capture-raise-billionsinfrastructure-4?utm_source=Citiscope\&utm_campaign=cea88514ce-Mailchimp_2014_01_21\&utm_medium= email\&utm_term=0_ce992dbfef-cea88514ce-71030809 (accessed on 19 September 2017).

31. Bradley, M.; Kenworthy, J. Congestion offsets: Transforming cities by letting buses compete. World Transp. Policy Pract. 2012, 18, 46-69.

32. Newman, P.; Kosonen, L.; Kenworthy, J. Theory of urban fabrics: Planning the walking, transit/transit and automobile/motor car cities for reduced car dependency. Town Plan. Rev. 2016, 87, 429-458. [CrossRef]

33. Priester, R.; Kenworthy, J.; Wulfhorst, G. The Diversity of Megacities Worldwide-Challenges for The Future of Mobility. In Megacity Mobility Culture: How Cities Move on in a Diverse World (Lecture Notes in Mobility); Institute for Mobility Research, Ed.; Springer: Munich, Germany, 2013; Chapter 2, pp. 23-54.

34. Klinger, T.; Kenworthy, J.; Lanzendorf, M. Dimensions of urban mobility cultures-A comparison of German cities. J. Transp. Geogr. 2013, 31, 18-29. [CrossRef] 
35. World Population Review. 2017. Available online: http://worldpopulationreview.com/world-cities/saopaulo-population/ (accessed on 18 September 2017).

36. Institute of Transport Engineering of the City of Prague. The Yearbook of Transport, Prague 2005; Institute of Transport Engineering of the City of Prague: Prague, Czech Republic, 2006. Available online: http: / / www.tsk-praha.cz/static/udi-rocenka-2005-en.pdf (accessed on 25 May 2014).

37. Watt, K.E.F.; Ayres, C. Urban land use patterns and transportation energy cost. In Proceedings of the 140th Annual Meeting of the American Association for the Advancement of Science (AAAS), San Francisco, CA, USA, 25 February 1974.

38. Goodwin, P.; Van Dender, K. 'Peak Car' -Themes and Issues. Transp. Rev. 2013, 33, 243-254. [CrossRef]

39. Metz, D. Peak Car and Beyond: The Fourth Era of Travel. Transp. Rev. 2013, 33, 255-270. [CrossRef]

40. Newman, P.; Kenworthy, J. Peak Car Use: Understanding the Demise of Automobile Dependence. World Transp. Policy Pract. 2011, 17, 32-42.

41. Gao, Y.; Kenworthy, J.; Newman, P. Growth of a Giant: A Historical and Current Perspective on the Chinese Automobile Industry. World Transp. Policy Pract. 2015, 21, 40-55.

42. World Bank. Earth Observation for Development: Historical Assessment of Spatial Growth of the Metropolitan Areas of Delhi, Mumbai and Dhaka. 2017. Available online: http: / /web.worldbank.org/WBSITE/EXTERNAL/TOPICS/EXTSDNET/EXTEOFD/0,,contentMDK: 23135639 pagePK:64168445 piPK:64168309 theSitePK:8426771,00.html (accessed on 28 September 2017).

43. Thomson, J.M. Great Cities and Their Traffic; Penguin Books: Middlesex, UK, 1977.

44. Mumbai Metropolitan Region Development Authority. Report 4: Field Survey (HIS and Other Surveys-Household Interview Survey; MMRDA: Mumbai, India, 2006; Volume 1.

45. Schiller, P.L.; Bruun, E.C.; Kenworthy, J.R. An Introduction to Sustainable Transport: Policy, Planning and Implementation; Earthscan: London, UK, 2010.

46. Cervero, R. The Transit Metropolis: A Global Inquiry; Island Press: Washington, DC, USA, 1998.

47. Gao, Y.; Kenworthy, J. China. In The Urban Transport Crisis in Emerging Economies; Pojani, D., Stead, D., Eds.; Springer Nature: Basel, Switzerland, 2017; Chapter 3, pp. 33-58.

48. Suwei, F.; Qiang, L. Car Ownership Control in Chinese Cities: Shanghai, Beijing and Guangzhou. Journeys, September 2013; pp. 40-49. Available online: http:/ / www.lta.gov.sg/ltaacademy/doc/13Sep040-Feng CarOwnershipControl.pdf (accessed on 22 January 2016).

49. Fjellstrom, K. High Capacity BRT Planning, Implementation and Operation: Case Study of the Guangzhou BRT. In Proceedings of the UNCRD EST Conference, Bangkok, Thailand, 24 August 2010; Institute for Transportation and Development Policy (ITDP): New York, NY, USA, 2010. Available online: http:/ / www. uncrd.or.jp/content/documents/5EST-B2B3.pdf (accessed on 2 October 2017).

50. Kenworthy, J.R.; Newman, P.W.G.; Barter, P.; Poboon, C. Is increasing automobile dependence inevitable in booming economies? Asian cities in an international context. IATSS Res. 1995, 19, 58-67.

51. Poboon, C. Anatomy of a Traffic Disaster: Towards a Sustainable Solution to Bangkok's Traffic Problems. Ph.D. Thesis, Murdoch University, Perth, Australia, 1997.

52. Kenworthy, J.R.; Townsend, C. An international comparative perspective on motorisation in urban China: Problems and prospects. IATSS Res. 2002, 26, 99-109. [CrossRef]

53. Pojani, D.; Stead, D. (Eds.) The Urban Transport Crisis in Emerging Economies; Springer Nature: Basel, Switzerland, 2017.

54. Kenworthy, J.R.; Hu, G. Transport and urban form in Chinese cities: An international and comparative policy perspective with implications for sustainable urban transport in China. DISP 2002, 151, 4-14. [CrossRef]

55. Rode, P. Urban planning and transport policy integration: The role of governance hierarchies and networks in London and Berlin. J. Urban Aff. 2017. [CrossRef]

56. Barter, P.; Dotson, E. Urban Transport Institutions and Governance and Integrated Land Use and Transport, Singapore. Case Study Prepared for Global Report on Human Settlements 2013. Available online: https:/ / unhabitat.org/wp-content/uploads/2013/06/GRHS.2013.Case_.Study_.Singapore.pdf (accessed on 24 October 2017).

57. Thi Phin, D.; Dotson, E. Urban Transport Institutions and Governance and Integrated Land Use and Transport, Hanoi, Viet Nam. Case Study Prepared for Global Report on Human Settlements 2013. Available online: https://unhabitat.org/wp-content/uploads/2013/06/GRHS.2013.Case_.Study_.Hanoi_ .Viet_.Nam_.pdf (accessed on 13 October 2017). 
58. Buehler, R.; Pucher, J. Sustainable Transport that Works: Lessons from Germany. World Transp. Policy Pract. 2009, 15, 13-46.

59. Buehler, R.; Pucher, J. Sustainable transport in Freiburg: Lessons from Germany's environmental capital. Int. J. Sustain. Transp. 2011, 5, 43-70. [CrossRef]

60. World Bank. Cycling Gains Ground on Latin American Streets. 2015. Available online: http://www. worldbank.org/en/news/feature/2015/06/24/el-pedaleo-gana-espacio-en-las-calles-latinoamericanas (accessed on 13 October 2017). 